Portland State University

PDXScholar

1990

\title{
John Rawls, the conception of a liberal self, and the communitarian critique
}

Johnathan Edward Mansfield

Portland State University

Follow this and additional works at: https://pdxscholar.library.pdx.edu/open_access_etds

Part of the Philosophy Commons, and the Political Science Commons

Let us know how access to this document benefits you.

\section{Recommended Citation}

Mansfield, Johnathan Edward, "John Rawls, the conception of a liberal self, and the communitarian critique" (1990). Dissertations and Theses. Paper 4142.

https://doi.org/10.15760/etd.6026

This Thesis is brought to you for free and open access. It has been accepted for inclusion in Dissertations and Theses by an authorized administrator of PDXScholar. Please contact us if we can make this document more accessible: pdxscholar@pdx.edu. 
AN ABSTRACT OF THE THESIS OF Johnathan Edward Mansfield for the Master of Science in Political Science presented July 3, 1990.

Title: John Rawls, the Conception of a Liberal Self, and the Communitarian Critique.

APPROVED BY THE MEMBERS OF THE THESIS COMMITTEE:
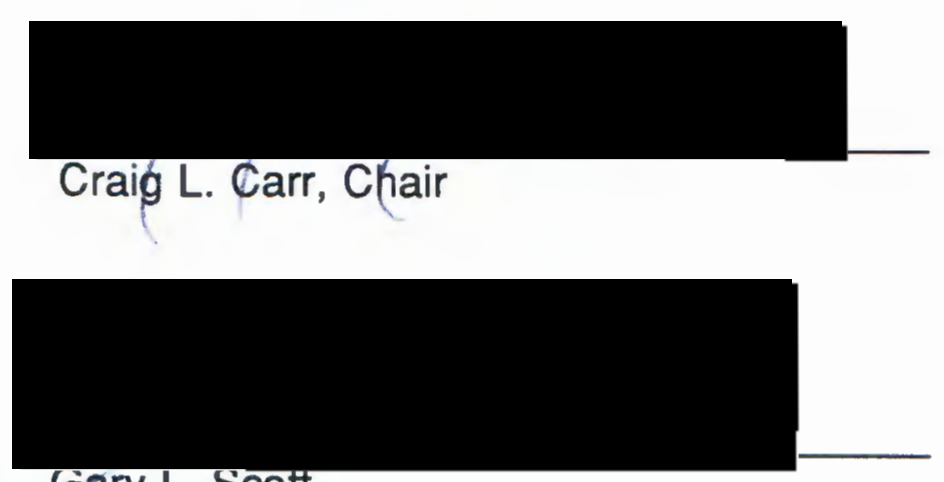

Gary L. scoit

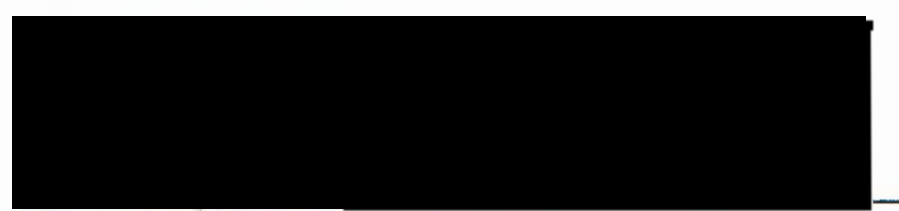

Byron L. Haines

John Rawls's $A$ Theory of Justice stands as the single most important work in the Anglo-American liberal tradition after World War II. In A Theory of Justice, Rawls revives the social contract doctrine in order to determine principles of justice that would be 
chosen by persons who are free and equal moral individuals. Since Rawls believes that no single conception of the good can establish justice in a pluralistic society, he posits a set of principles of right which are prior to any particular good. Thus his theory, which he calls "justice as fairness," is deontological. Since its publication in 1971, A Theory of Justice has generated extensive critical response from writers all along the philosophical spectrum.

A group of thinkers loosely classified as "communitarians" have levelled a number of criticisms at the conception of the person they claim is presumed in justice as fairness. Communitarians generally contend that the Rawlsian liberal self is overly individualistic, and that therefore justice as fairness is insufficient to provide for important shared and communal values.

Communitarians such as Michael Sandel have criticized Rawis's idea of the self as being overly abstract. Charles Taylor has argued that liberals such as Rawls have failed to take into consideration the extent to which we are situated in a culture. Many of these "mainstream" communitarian objections echo Hegel's criticisms of the Kantian noumenal self. This thesis will present the ideas of the Hegelians, such as Sandel and Taylor, and the neo-Aristotelian varient of communitarianism of Alasdair Maclntyre.

Since the publication of $\boldsymbol{A}$ Theory of Justice, Rawls has produced a steady stream of articles that expand and clarify the principles of justice as fairness. This thesis will argue that during the 1980's, Rawls moved the emphasis of his theory away from an attempt to find universalist truths, and towards a search for a 
'political' morality. Rawls claims that we can find a conception of persons as free and equal moral beings that will serve as a basis for constructing a political morality that will establish the principles of right. This idea of the person I refer to as the 'Kantian shell.' Though all citizens would be governed by this political morality, it would not interfere with their private, comprehensive ideas of the good. The public and the private spheres remain discrete, and thus Rawls's political morality remains neutral between individuals' ideas of the good.

I will argue that Rawls's attempt to use a Kantian shell to construct a political conception of justice fails on two grounds. First, though the political morality must be neutral between conceptions of the good in order to be fair, the Kantian shell is biased towards certain goods and excludes others. Second, the aspects of the Rawlsian person are ultimately insufficient to avoid the problems of the Kantian transcendental self. The individual liberal self is an abstraction that leaves out important parts of what it means to be a person. Rawls's movement from metaphysical to political thus fails to adequately engage the communitarian critique. 
JOHN RAWLS, THE CONCEPTION OF A LIBERAL SELF, AND THE COMMUNITARIAN CRITIQUE

\author{
by \\ JOHNATHAN EDWARD MANSFIELD
}

A thesis submitted in partial fulfillment of the requirements for the degree of

\title{
MASTER OF SCIENCE \\ in \\ POLITICAL SCIENCE
}

Portland State University

1990 
TO THE OFFICE OF GRADUATE STUDIES:

The members of the Committee approve the thesis of Johnathan Edward Mansfield presented July 3, 1990.

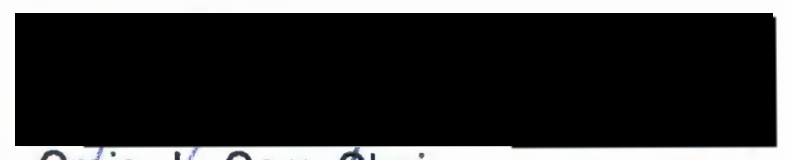

Cräig W. Carr, chair

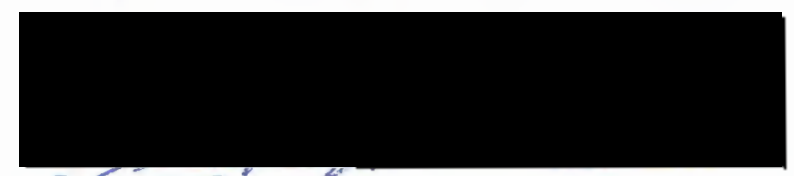

Gary L. Scott

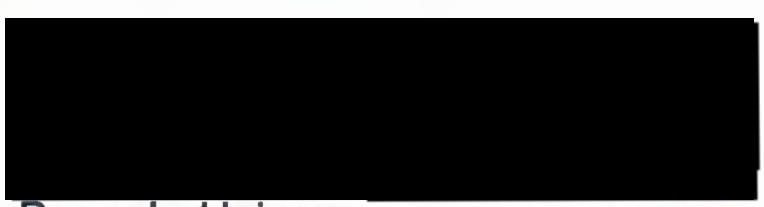

Byron L. Haines

\section{APPROVED:}

Gary L. Scott, Chair, Department of Political Science

C. William Savery, Interim Vice Provest for Graduate Studies and Research 


\section{ACKNOWLEDGEMENTS}

The advice, training and support that I have received from $\mathrm{Dr}$. Craig Carr have been of inestimable value to me. Thanks are also due to my parents, and of course to WPB. 


\section{TABLE OF CONTENTS}

\section{PAGE}

ACKNOWLEDGEMENTS

$\mathrm{iii}$

CHAPTER

I INTRODUCTION

II RAWLS'S ORIGINAL CONCEPT OF SELF IN A THEORY OF JUSTICE

1. The Original Position

2. Individuality

3. Mutual Disinterest

4. Equality

5. Rationality, Autonomy, and Choice

6. Societal Considerations

7. Conclusion: The Rawlsian Self

III COMMUNITARIAN CRITIQUES: MICHAEL SANDEL AND CHARLES TAYLOR

1. Michael Sandel's Critique of the Rawlsian 32 Self

2. The Antecedently Individuated Self

3. The Self as a Chooser of Its Ends 
4. The Incompatibility of the Rawlsian Self with Cognitive Aspects

5. The Volitional Aspect of the Rawlsian

Self as Insufficient to Account for Communal Ends

6. Taylor, Hegel, and Partial Communities 42

7. 'Sittlichkeit' and 'Moralität' 43

8. The Communal Identity of the Self 44

9. Hegel on Freedom and Equality in Modern Society

10. Atomism, Freedom, and the Liberal Self 48

11. The Situatedness of Rights 49

12. Rights and the Obligation to Belong 52

13. Communitarians and the Situated Self 54

IV ALASDAIR MACINTYRE AND THE NEO-ARISTOTELIAN CRITIQUE

1. The Search For the Unity of the Self 58

2. The Narrative Concept of the Self 60

3. Teleology and the Narrative Self 62

4. The Good, and the Sense of a Tradition 64

5. Macintyre as a Neo-Aristotelian

Communitarian

66

$\checkmark$ RAWLS'S REJOINDER: TOWARDS A POLITICAL CONCEPTION OF THE SELF 
1. Kantian Constructivism

2. The Kantian Self

3. Kantian Constructivism as a Justificatory Scheme

4. Justice as Fairness: Political not Metaphysical

5. The Common Idea of a Self in a Political Conception

6. The Idea of an Overlapping Consensus 84

7. Aspects of the Overlapping Consensus 88

8. Objections to the Overlapping Consensus 90

9. On the Idea of Free Public Reason

93

10. Conclusion: From Metaphysical to Political

1. The Shift From Metaphysical to Political

2. The "Kantian Shell" as a Foundation of Justice as Fairness

3. A Neutral Conception?

4. The Incomplete Individual 


\section{CHAPTER I}

\section{INTRODUCTION}

The ideas of every philosopher concerned with human affairs in the end rest on his conception of what man is and can be. To understand such thinkers, it is more important to grasp this central notion or image, which may be implicit, but determines their picture of the world, than even the most forceful arguments with which they defend their views and refute actual and possible objections.

Isaiah Berlin

If we use the number of critical works about an author as a measure of his importance, John Rawls is clearly the leading political philosopher alive today. We may speculate that this is because of Rawls's continuing commitment to the particular liberal philosophy that he calls "justice as fairness." manuscript drafts that predate $A$ Theory of Justice, to $A$ Theory of Justice itself, and including numerous articles since $A$ Theory of Justice, Rawls has focused almost exclusively on explicating and

1See $A$ Theory of Justice (Cambridge, MA, The Belknap Press of Harvard University Press, 1971)( hereafter referred to as TJ). 
amending his version of liberal theory. His single-minded attention has built a conceptual edifice that aspires to be systematic, wellsupported, and complete within its defined scope.

Rawls's work has generated a small industry of criticism from both supporters and detractors. Interestingly enough, both camps seem to share a common reason for their interest in Rawls, whom they see as the paradigmatic deontological liberal theorist. For those inclined towards liberalism, his work provides the strongest general statement of these beliefs. And anti-liberals, both conservative and radical, are attracted to Rawls as the opposing champion of the liberal forces. If they can defeat what they consider to be the best-supported example of liberalism, perhaps they may deal liberalism in general a death-blow. Rawls's work serves as a playing field for those who would engage in either side of the liberal debate.

Much of the criticism of Rawls and liberalism generally has been directed towards the liberal concept of the person.2 Initially, this may seem puzzling. After all, we all know what a person is, don't we? But an examination of issues like abortion, euthanasia, and even animal "rights" indicates much contention over the characteristics we believe a person has. Even when we agree upon which things are indeed persons, there is still controversy about what it actually means to be a person. It is possible that a system that primarily values the good of the community will ascribe

2 will use the words "person" and "self" interchangeably in this paper, unless otherwise noted. 
different traits to a person than does a system that esteems the individual. In this way, the values of a given political philosophy bear some relationship to the conception of a person.

Writers as diverse as Roberto Unger and Alasdair Maclntyre have claimed that liberalism presumes a self that is impoverished or incoherent. ${ }^{3}$ Michael Sandel has written a book-length critique of Rawls's liberalism that argues that not only is the liberal self impoverished, but that this conception is also inconsistent with liberal values. ${ }^{4}$ These responses to $A$ Theory of Justice are not peripheral. As the quotation from Isaiah Berlin implies, the question of self is central to a political theory. An important way to test a political theory is to see how it affects persons.

Perhaps the most developed line of criticism of the liberal self has come from the group of thinkers commonly known as "communitarians." Allen Buchanan has outlined the communitarian critical program as follows:

i) Liberalism devalues, neglects, and/or undermines community, and community is a fundamental...ingredient in the good life for human beings.

ii) Liberalism undervalues political life-viewing political association as a merely instrumental good, it is blind to the fundamental importance of full participation

${ }^{3}$ See, for example, Unger's Knowledge and Politics (New York: The Free Press, 1975) and Maclntyre's After Virtue (South Bend, Indiana: Notre Dame University Press, 1984-2nd ed.). 
in political community for the good life for human beings.

iii) Liberalism fails to provide...an adequate account of the importance of certain types of obligations and commitments-those that are not chosen or explicitly undertaken through contracting or promising-such as familial obligations and obligations to support one's community or country.

iv) Liberalism presupposes a defective conception of the self, failing to recognize that the self is "embedded" in and partly constituted by communal commitments and values which are not objects of choice.

v) Liberalism wrongly exalts justice as being "the first virtue of social institutions," failing to see that, at best, justice is a remedial value, needed only in circumstances in which the higher value of community has broken down. 5

Rawls has certainly been the subject of other, non-communitarian critiques. But communitarians, particularly Michael Sandel and Charles Taylor, have focused a significant portion of their writing on the question that I am interested in, namely, the liberal conception of the self as seen in the work of Rawls.

This line of criticism has not gone unanswered by Rawls. In several of his later articles, he has attempted to respond to his critics by altering his conception of the liberal self. 6 Specifically,

${ }^{5}$ Allen E. Buchanan, "Assessing the Communitarian Critique of Liberalism," Ethics, v. 99 \#4 (July 1989), p. 852-853.

6See esp. the following essays by Rawls: "Kantian Constructivism in Moral Theory: The Dewey Lectures 1980," Journal 
Rawls has undertaken to distance what he refers to as the "public" conception of the self from the myriad "private" conceptions held by various individuals. The Rawlsian public self is to be based upon as few contentious assumptions as possible. By positing a "thin" and hopefully uncontroversial public self, Rawls claims that justice as fairness can allow the greatest possible latitude for private conceptions of the person. Thus, the liberal value of neutrality between conceptions of the good will remain intact.

This looks very much like the traditional liberal move of separating the public and the private realms. But Rawls disavows the idea that justice as fairness promotes an instrumentalist "private society," composed of individuals who associate only to further their personal aims. He understands the principles of justice that comprise his theory as allowing and encouraging communal and shared ends. But he feels that the public conception of the self is necessary to ensure that these principles of justice represent certain essential aspects of persons.

Rawls makes a valiant effort to remain neutral between various conceptions of the self, but I will argue that he ultimately fails. Justice as fairness does have room for some different ideas of the self. But due to the deontological formulation of Rawls's theory, all conceptions of the person must share in some way the

of Philosophy 77 (1980): 515-72; "Justice as Fairness: Political not Metaphysical," Philosophy and Public Affairs 14 (1985): 22351; "The Idea of an Overlapping Consensus," Oxford Journal of Legal Studies 7 (1987): 1-25, and "The Idea of Free Public Reason," 1988 (unpublished lecture). 
characteristics of the public self. Given the fact of pluralism, which Rawls insists forms part of the situation of justice, we can conceive of many conceptions of a person that could be found in our culture that are incompatible with Rawls's public self. Thus, justice as fairness is no more neutral towards widely divergent selves than the traditional dress code of tennis, which allows a player to wear any color so long as it is white.

Rawls has been developing justice as fairness at least since the late 1950's, but his major (and only) book-length treatment of this idea is in $A$ Theory of Justice. The first chapter of this paper will examine the details of the concept of the self found therein.

As Buchanan has noted, "[t]he communitarian challenge achieves its most powerful expression in the works of Alasdair MacIntyre, Charles Taylor, and Michael Sandel."7 Chapter III will be devoted to an examination of the work of Sandel and Taylor. For reasons that I will discuss in the beginning of chapter III, Macintyre differs from"mainstream" communitarians such as Taylor and Sandel in important ways. Therefore, I will discuss his writing in a separate chapter (chapter IV). Though other writers' works contain communitarian elements, 8 I will limit this discussion essentially to the ideas of Sandel, Taylor, and Maclntyre. My aim is more to focus 852.

7"Assessing the Communitarian Critique of Liberalism," $p$.

${ }^{8}$ Notably Michael Oakeshott, Michael Walzer, Peter Berger, Richard Rorty and possibly Roberto Unger. 
upon Rawls's response to this line of criticism than to examine the entire range of communitarian critique.

In chapter V I will examine Rawls's attempt to rebut the communitarian critique of his conception of the self in several selected articles published since $A$ Theory of Justice. ${ }^{9}$ I will argue that though Rawls is clearly aware of the potential impact of several of these arguments on justice as fairness and liberalism in general, he has failed to satisfactorily adapt his conception of the self to meet these criticisms.

9Specifically, "Kantian Constructivism in Moral Theory: The Dewey Lectures 1980," Journal of Philosophy 77 (1980): 515-72; "Justice as Fairness: Political not Metaphysical," Philosophy and Public Affairs 14 (1985): 223-51; and "The Idea of an Overlapping Consensus," Oxford Journal of Legal Studies 7 (1987): 1-25, and "The Idea of Free Public Reason," 1988 (unpublished lecture). 


\section{CHAPTER II}

RAWLS'S ORIGINAL CONCEPTION OF THE SELF IN A THEORY OF JUSTICE

Rawls treats the concept of the self somewhat obliquely in $A$ Theory of Justice. In no single place does he discuss the characteristics of the self in justice as fairness. This is understandable, since Rawls, by his own admission, is attempting to base his theory on "...widely accepted but weak premises..." We can see why a deontological liberal might want to choose this approach. Presumably, the weaker the premises underlying the theory are, the closer it can approach substantive neutrality between contending conceptions of the good. The idea behind this is that the good for a self is inextricably bound up in the conception of a person. If the theory is seen as having a strong basis in a particular conception of the self, the claim of neutrality will be difficult to maintain.

But it is true that a conception of the person must have some characteristics in order to be such a conception. The structure of the discussion in $T J$ is not really a deductive argument. Rather, it is closer to a web in which interconnecting strands variously reinforce each other. 1 Thus is is necessary to tease these characteristics out of the text of $T J$.

1 The idea of Rawls's web of argument comes from Brian Barry, The Liberal Theory of Justice: a critical examination of the principal 


\section{THE ORIGINAL POSITION}

Much of Rawls's conception of the self is seen in his exposition of what he calls the original position. ${ }^{2}$ Norman Daniels claims that the original position, "...Rawls' attempt to revive a version of the social contract,...[is] the most distinctive feature of $A$ Theory of Justice...."3 The original position is not an assertion of a particular conception of the person as such; rather, it is a justification for the concepts of justice as fairness:

...the original position of equality corresponds to the state of nature in the traditional theory of the social contract. This original position is not, of course, thought of as an actual historical state of affairs, much less as a primitive condition of culture. It is understood as a purely hypothetical situation characterized so as to lead to a certain conception of justice. 4

Though the original position need not ever have existed, it presumably represents our best considered judgments of a situation that would be fair. We can "step into" this position at any time, and use it to determine principles of justice. Because of the

doctrines in A Theory of Justice by John Raw/s (Oxford: Clarendon Press, 1973).

2See especially $\S 2, \S 3, \S 4$, and Chapter III of $T J$.

${ }^{3}$ Norman Daniels, "Introduction," Reading Rawls (New York: Basic Books, 1973), p. xviii.

${ }^{4} T J$, p. 12 (footnote omitted). 
restrictions imposed in this situation, we can supposedly be assured that the principles that we choose are "fair."5

It is clear that the restrictions that are assumed in the original position will affect the outcome of our deliberations in some way. Rawls wishes to argue from "...widely accepted but weak premises to more specific conclusions."6 Ideally, according to Rawls, these premises would lead to a determinate conception of justice. The premises that 1 will deal with below are the assumptions and claims that Rawls makes about persons. These comprise Rawls's concept of the self in $A$ Theory of Justice.

Rawls makes two essential claims about the original position. First, he asserts that the premises posited in the original position are weak, but widely acceptable. Second, Rawls argues that these premises will lead to the conception that he describes as justice as fairness. My next step will be to examine the characteristics of the Rawlsian self.

\section{INDIVIDUALITY}

An essential aspect of the Rawlsian self is her individuality. Put another way, the individual person is the ultimate unit of Rawls's conception:

5 Thomas Nagel, "Rawls on Justice," Reading Raw/s, p. 6. $6 T J$, p. 18. 
Each person possesses an inviolability founded on justice that even the welfare of society as a whole cannot override...It does not allow that the sacrifices imposed on a few are outweighed by the larger sum of advantages enjoyed by many...Therefore in a just society the liberties of equal citizenship are taken as settled....7

Rawls's emphasis on the individual is seen especially in his comments about utilitarianism. Rawls's difficulty with utilitarian strategies lies in his belief that these theories conflate individual desires into the desires of a single, artificially constructed "conglomerative being." Utilitarianism's ultimate unit is society as a whole, and thus "...does not take seriously the distinction between persons." 8 Justice as fairness, then, is principally concerned with people as distinct entities.

\section{MUTUAL DISINTEREST}

The question of the self-interest (or mutual disinterest) of individuals is a difficult one for Rawls. In his introductory remarks, he states:

One feature of justice as fairness is to think of the parties in the initial situation as rational and mutually disinterested. This does not mean that the parties are

$7 T J$, p. 3-4.

8TJ, p. 27. 
egoists...But they are conceived as not taking

an interest in one another's interests. ${ }^{9}$

It is necessary that this assumption be made in order for the original position argument to function at all. If individuals might make choices that were not in their "own" best interests, it is difficult to predict what the outcome of the original position might be.

But Rawls's claim of mutual disinterest is not merely an heuristic device, designed to determine the outcome of a theoretical construction. He is also advancing a proposition about the psychology of people in general:

I also suppose that men suffer from various shortcomings of knowledge, thought, and judgment...their judgment is likely to be distorted by anxiety, bias, and a preoccupation with their own affairs...to a large degree, [this is] simply part of men's natural situation. 10

The difficulty that an observer may have with Rawls's conception of mutual disinterest is in determining whether it is meant to describe people as representatives in the original position, to describe the "natural situation" of mankind, or some combination of both. Remember that the original position

...is meant to incorporate widely shared and yet weak conditions. A conception of justice should not presuppose, then, extensive ties of

$9 T J$, p. 13.

10 TJ, p. 127. 
natural sentiment. At the basis of the theory, one tries to assume as little as possible. ${ }^{11}$

In $T J$ then, Rawls maintains that mutual disinterest is a weaker, and therefore more widely acceptable, assumption than an opposing view in which persons are collectively interested. We have already seen that the original position requires mutual disinterest, and it is evident that Rawls claims that mutual disinterest is also widely acceptable as a characteristic of the self.

The most immediate challenge to the assumption of mutual disinterestedness is the question of familial affinity. Do not the sacrifices of parents for children, and siblings for each other provide a common counter-example to disinterest? Rawls responds to this by assuming that persons are to be thought of as

...representing continuing lines of claims, as being, so to speak, deputies for a kind of everlasting moral agent or institution...each person in the original position should care about the well-being of some of those in the next generation...Moreover for anyone in the next generation, there is someone who cares about him in the present generation. 12

This appears to be a plausible assumption (Rawls calls it a "motivational assumption"). ${ }^{13}$ Our parents care for our interests,

11 TJ, p. 129.

12 TJ, p. $128-129$.

$13 T J$, p. 128. 
we care for the interests of our children, and so on. ${ }^{14}$ But the idea of persons as representing "lines of claims" is not contrary to the assumption of mutual disinterest. We must be raised by our parents, as a result of at least biological necessity. If we decide to have a child of our own, we do so as a result of calculations made from the perspective of our own conception of the good. The decision to have a child entails enduring the attendant sacrifices that this involves.

\section{EQUALITY}

In one of the first reviews of $T J$, Thomas Nagel writes:

Rawls' substantive doctrine is a rather pure form of egalitarian liberalism, whose controversial elements are its egalitarianism, its anti-perfectionism and anti-meritocracy, the primacy it gives to liberty, and the fact that it is more egalitarian about liberty than about other goods. ${ }^{15}$

Rawls's views on equality in $T J$ can be divided into a moral conception and a political conception.

Rawls assumes a priori that persons are morally equal beings. ${ }^{16}$ For him, moral beings

${ }^{14}$ For a view of this process based upon genetic determinism, see Richard Dawkins, The Selfish Gene (New York: Oxford University Press, 1976).

${ }^{15} \mathrm{Nagel}$, "Rawls on Justice," p. 3.

${ }^{16} T J$, p. 19. 
...are distinguished by two features: first they are capable of having...a conception of their good (as expressed by a rational plan of life); and second they are capable of having...a sense of justice, a normally effective desire to apply and to act upon the principles of justice, at least to a certain minimum degree. ${ }^{17}$

In order to avoid problems in determining which persons have the requisite "moral personality," we are to assume that everyone has a sufficient level. ${ }^{18}$ Those who are unlucky, in the sense of not possessing this moral personality, are "contingently disadvantaged." We should therefore not hold this circumstance against them in the distribution of justice.

Rawls notes that some may argue against basing egalitarianism upon natural capacities. After all, should not those who have more "natural moral ability" (according to the criteria given above) reasonably get "more justice?" If so, egalitarianism cannot be based upon natural capacities. But Rawls posits that the range of capacity is broad enough to encompass all persons, so that we need not make distinctions regarding moral capacities. All those who are inside the range conditions, i.e., all humanity, are moral beings and are thus deserving of justice. ${ }^{19}$

17 TJ, p. 505.

18 TJ, p. 506.

19 TJ, p. 508. 
We have seen that Rawls assumes that all persons are moral beings. Therefore, all persons are entitled to equal justice, and this is taken into account in Rawls's political conception of equality. The primary device for ensuring this equality in the original position is the veil of ignorance. 20 Since the idea of the original position is to determine a system of justice that is fair, we must treat the participants as equals: "[s]omehow we must nullify the effects of specific contingencies which put men at odds and tempt them to exploit social and natural circumstances to their own advantage."21 Men are at odds because of Rawls's inclusion in the circumstances of justice 22 a Humean assumption of "...moderate scarcity understood to cover a wide range of situations." 23 Since the persons in the original position are mutually disinterested individuals grappling for scarce resources, it is reasonable to imagine that they will be "at odds" in trying to establish a distributive system.

But the more controversial idea expressed here is Rawls's anti-meritocratic bent. Rawls admits as much: "There is a natural inclination to object that those better situated deserve their greater advantages whether or not they are to the benefit of

20 See especially $T J, \S 24$.

$21 \mathrm{TJ}$, p. 136.

22The circumstances of justice are discussed in TJ, $\S 22$. ${ }^{23} T J$, p. 127. 
others." 24 However, he claims that upon reflection, we will arrive at the opposite conclusion:

It seems to be one of the fixed points of our considered judgements that no one deserves his place in the distribution of native endowments, any more than one deserves one's initial starting place in society. ${ }^{25}$

Since these "contingencies of endowment" are morally arbitrary, persons in the original position may not use them to determine a system of justice, even though as self-interested individuals it is rational for them to do so. Rawls's solution to this problem is to assume that persons in the original position do not know certain specified things. They are under a veil of ignorance. Essentially, these persons are unaware of exactly the types of morally arbitrary and contingent attributes that might lead them to choose a system of justice that is more fair to themselves and others with similar characteristics. These include their own particular talents and abilities, intelligence, strength, and particular conceptions of the $\operatorname{good} .26$

About the only things which persons in the original position are allowed to know "...is that their society is subject to the circumstances of justice and...they understand political affairs and the principles of economic theory; they know the basis of social
$24 T J$, p. 103.
$25 T J$. p. 104.
$26 T J$, p. 137. 
organization and the laws of human psychology."27 The persons know that they are equal moral beings with a capacity for a sense of justice.

They also know that they have a particular conception of the good, though they do not know anything of its substance. This is part of a person's moral nature. ${ }^{28}$ We can see here how Rawls's deontological ethic fits into his conception of the self. Though having a good generally is an essential part of moral personality, any particular conception of the good is not. The principles of right are to be determined before any specific ideas of the good are known. In justice as fairness, therefore, a person's sense of right is prior to her conception of the good. This does not imply that one is superior to the other. Rather, this lexical order must hold if egalitarianism is to obtain.

It is this essential moral conception of equality that leads to Rawls's political egalitarianism. Because of the veil of ignorance ensures equality, Rawls claims that the principles of justice chosen by persons in the original position will be fair. These principles form the substance of justice as fairness:

First: each person is to have an equal right to the most extensive basic liberty compatible with a similar liberty for others. ${ }^{29}$ [Principle of equal liberty]

27 TJ, p. 137.

$28 \mathrm{TJ}$, p. 505.

$29 \mathrm{TJ}$, p. 60. 
Second: social and economic inequalities are to be arranged so that they are both (a) to the greatest benefit of the least advantaged and (b) attached to offices and positions open to all under conditions of fair equality of opportunity. 30 [The Difference Principle]

The first principle is fairly straightforward. I only note here that its use of persons as the primary subject of equality follows from Rawls's emphasis on individuality. I will discuss its Kantian aspects below in the section on rationality, autonomy and choice (this chapter, § 5).

The main function of the difference principle is to redress naturally contingent inequalities. Rawls realizes that the natural lottery by which talents and attributes are "distributed" is neither fair nor unfair; it is merely arbitrary from the standpoint of justice. But fairness is, of course, what Rawls is after. Since persons have equal moral personality and deserve justice, he must design a theory of justice that benefits the least advantaged, at least to some degree. By doing so, this political conception of justice respects persons' essential moral equality

\section{RATIONALITY, AUTONOMY, AND CHOICE}

It is essential that parties in the original position be rational choosers. To assume otherwise would undercut the predictability of 
the outcome of the original position. Remember that parties to the original position "...know that they have some rational plan of life, [but] they do not know the details of this plan, the particular ends and interests which it is calculated to promote." 31 Rawls has posited a set of primary goods that are means to any ends which a rationa|32 person might have. ${ }^{33}$ Since the means to any potential conception of the good are supposedly available within the set of primary goods, it is rational for a person to want more of these goods rather than less. ${ }^{34}$ By doing so, she will stand the greatest chance of advancing her own particular conception of the good.

We can observe the link between Rawls's understanding of rationality and several principles I have already discussed. It is rational, in justice as fairness, to make decisions as an individual. It would deny the primacy of the individual for a person in the original position to choose principles that benefit any unit other than the individual. And it would be irrational for a person to be anything other than self-interested.

It is important to note here the relation of Rawls's view of rationality to his concept of moral personality. According to Rawls,

31 TJ, p. 142.

$32 T J$, p. 62.

${ }^{33} T J, \S 15$.

$34 T J$, p. 142. 
this concept is strongly influenced by certain aspects of Kant's conception of persons: ${ }^{35}$

Kant held, I believe, that a person is acting autonomously when the principles of his action are chosen by him as the most adequate possible expression of his nature as a free and equal rational being...For to express one's nature as a being of a particular kind is to act on the principles that would be chosen if this nature were the decisive determining element. ${ }^{36}$

Rawls sees persons as free and equal, and thus autonomous, beings. Treating people as moral entities, i.e., according to the principles of justice, is a categorical imperative for humanity. ${ }^{37}$ When we assume that the persons in the original position have these characteristics, it follows that they will express their nature as rational beings by acting on principles that will ensure their own autonomy. It is rational for them, then, as self-interested individuals, to choose the two principles of justice as fairness. At the time of the original position, they do not know which specific characteristics will be allotted them in the scheme of natural distribution. Thus for the Rawlsian self, it is rational to be prudent-to choose the principles that will guarantee one the highest

$35 T J$, p. 251.

$36 T J$, p. $252-253$.

37 TJ, p. 253. 
possible minimum welfare. Rawls refers to this concept as "maximin." 38

Though Rawls claims that his conception of rationality is Kantian, a closer examination indicates that it may be closer to Hume than Kant. For Kant, "...reason...recognizes as its highest practical function the establishment of a good will [i.e., morality]..."39 But it is essential that reason be grounded properly:

...Do we not think it a matter of the utmost necessity to work out for once a pure moral philosophy completely cleansed of everything that can only be empirical and appropriate to anthropology?...[T]he ground of obligation [to moral laws] must be looked for, not in the nature of man nor in the circumstances in which he is placed, but solely a priori in the concepts of pure reason....[emphasis added] ${ }^{40}$

This means, as Otfried Höffe observes, that according to Kant:

[J]ustice or the moral concept of right cannot be based upon assertions about human nature, i.e. on a practical or empirical anthropology, but must be given a purely rational (a priori) foundation in terms of pure practical reason. 41

${ }^{38} \mathrm{TJ}, \quad$ p. $152 \mathrm{ff}$.

39Immanuel Kant, Groundwork of the Metaphysic of Morals, trans. H. J. Paton (New York: Harper and Row, 1948), p. 64.

${ }^{40}$ Groundwork of the Metaphysic of Morals, p. 57.

41 Otfried Höffe, "Is Rawls' Theory of Justice really Kantian?," Ratio XXVI 2 1984, p. 104. 
But it appears that Rawls's concept of primary social goods is evidence that aspects of justice as fairness are based on 'practical or empirical anthropology.'42 Remember that these primary goods are (unspecified) means to ends, these ends being specific conceptions of the good that individuals will have in the real world. But these primary goods must have at least some "broad" definitions, which Rawls gives as: "...rights and liberties, opportunities and powers, income and wealth...[a] very important primary good is a sense of one's own worth...."43 Clearly, these broad categories are themselves derived from certain intuitively known "facts" of 'practical or empirical anthropology,' which are given a priori.

As I noted above, Rawls conception of rationality owes a greater debt to Hume than to Kant. 44 Rawls states that in justice as fairness, we
...avoid attributing to the parties [in the original position] any ethical motivation.
They decide solely on the basis of what seems best calculated to further their interests so far as they can ascertain them. In this way we can exploit the intuitive idea of rational prudential choice. ${ }^{45}$

42“Is Rawls' Theory of Justice really Kantian?," p. 105. ${ }^{43} T J$, p. 92.

${ }^{44}$ For the idea of Rawls's Humean sense of rationality, I am indebted to Dr. Craig Carr, Portland State University.

$45 T J$, p. 584. 
However, this rational prudential choice is not Kantian. Once again, Höffe notes that

Prudential precepts represent (pragmatic-)

hypothetical imperatives, not categorical

imperatives; since they are heteronomous and

arise from considerations of our own well-

being, they represent the very opposite of

Kant's moral principle of autonomy. 46

Rather, this sounds much more like Hume's claim that "...self-

interest is the original motive to the establishment of

justice....[emphasis in original] 47 Hume holds a purely instrumental

view of reason (e.g., rationality): "Reason is, and ought only to be the slave of the passions, and can never pretend to any other office than to serve and obey them." 48 If the parties to the original position are motivated by prudent self-interest rather than ethical motivations, as Rawls explicitly states that they are, these persons are rational in a Humean, not a Kantian, sense, in spite of Rawls's protestations to the contrary.

It is understandable that Rawls looks to Kant as a intellectual model. As noted above, Rawls is clear in his objections to utilitarianism, particularly on individualist grounds. Höffe notes that

46“Is Rawls' Theory of Justice really Kantian?," p. 105.

47David Hume, $A$ Treatise of Human Nature, ed. L.A. SelbyBigge, Oxford: Clarendon Press, 1888, p. 499.

${ }^{48}$ A Treatise of Human Nature, p. 415. 
Since utilitarianism represents an empiricopragmatic ethic and a normative political philosophy, the most significant alternative model to it is to be found in Kant's system of a priori and categorical morality. It is therefore reasonable that Rawls should refer back to certain fundamental ideas of Kant and consider his own anti-utilitarian theory of justice as Kantian in inspiration....49

It is especially understandable that Rawls wishes to deny his debt to Hume, since Hume is often seen as a proto-utilitarian.50 But insofar as Rawls holds the conception of rationality expounded in $T J$, he is Humean.

Rawls also holds the view that "...moral principles are the object of rational choice." 51 The principles of justice that the original position is to justify must be rationally chosen by free and equal moral persons. If these principles are not the result of (rational) choice, it is difficult to claim that the parties to the original position are autonomous.

\section{SOCIETAL CONSIDERATIONS}

Though Rawls appears to hold individualistic premises, he is concerned with the relation of justice as fairness to the values of community:

49"Is Rawls' Theory of Justice really Kantian?," p. 103.

50This point comes from Dr. Craig Carr.

51 TJ, p. 251. 
We have already seen that despite the individualistic features of justice as fairness, the two principles of justice provide an Archimedean point for appraising existing institutions...But the question remains whether the contract doctrine is a satisfactory framework for understanding the values of community and for choosing among social arrangements to realize them. 52

One way to understand justice as fairness is as a "private society." 53 In a private society, "...each person assesses social arrangements solely as a means to his private aims."54 Citizens are self-interested and have an instrumentalist conception of the institutions comprising society. Though Rawls acknowledges that this is a possible interpretation of a well-ordered (i.e., fair) society, he prefers another explanation. This is the idea of a "social union." 55

The conception of a social union begins with this idea of persons in society:

...one basic characteristic of human beings is that no one person can do everything that he might do; nor a fortiori can he do everything that any other person can do...Different persons with similar or complementary capacities may cooperate so to speak in

$52 T J$, p. 520.

$53 T J$, p. 521.

$54 T J$, p. 521.

$55 \mathrm{TJ}, \S 79$. 
realizing their common or matching

nature...[thus] it is through social union...that

each person can participate in the total sum

of the realized natural assets of the others. 56

According to the Kantian conception, persons can more fully realize their nature as moral beings in this type of social union, and thus "[i]t follows that the collective activity of justice is the preeminent form of human flourishing." 57 The institutions of a well-ordered society are valued as ends in themselves, rather than merely as instrumentalist means to individual ends, as they are in a private society. 58 In the largest sense, justice as fairness is "...a social union of social unions."59 Rawls claims that the concept of a social union, rather than that of a private society, gives the most satisfactory account of how justice as fairness supports community values.

\section{CONCLUSION: THE RAWLSIAN SELF}

What, finally, is the concept of a self that Rawls presumes in A Theory of Justice ? At one level, it would be most satisfactory for Rawls to deny any specific concept of the self. By doing so, he could conceivably achieve neutrality between competing conceptions

56 TJ, p. 523.

$57 T J$, p. $528-529$.

$58 T J$, p. 527.

59 TJ, p. 527. 
of the good. But Rawls feels that justice must take into consideration the Humean stipulation of "...a conflict as well as an identity of interests." 60 In other words, not all conceptions of the good can coexist. Thus, we must establish a system of right to order a just society.

Rawls realizes that if he bases a theory of justice on strong premises, it may be attacked on the grounds that it is rooted in nonneutral principles. Therefore, Rawls wants to establish ideas of justice based on weak principles. Presumably, these principles are not principles of the good, but rather of the right. By placing the right before the good, neutrality between competing conceptions of the good can be established.

Rawls does not perspicuously expound a conception of the person. As mentioned above, to do so might open justice as fairness to charges of non-neutrality. But he does describe characteristics of the persons in the original position. These persons are hypothetical "representatives" of people who (at least potentially) actually exist in a society.

In the original position, the individual is the principle unit of discussion. All individuals are to be presumed as equally possessing moral personality, which is the capability for having a specific conception of the good, as well as of a sense of justice. These individuals are self-interested, but are deprived of any specific 
information about themselves that might cause them to choose principles that are not fair.

The moral principles that are the outcome of the original position are the products of rational choice. Persons choose these principles because they are autonomous, in a Kantian sense, and doing this expresses their essential nature as free and equal moral beings. The parties are rational according to Rawls's understanding. Since they do not know what their specific conception of the good will be outside of the original position, they will opt for prudent principles that will guarantee the highest minimum level of welfare whatever their eventual situation might be.

Though justice as fairness has strong individualistic aspects, it supposedly does not deny the importance of community. Rawls claims that persons are fully expressing their moral personality by entering into a social union of social unions.

These are what I understand to be the essential aspects of the original Rawlsian self, according to the theory of justice as fairness expressed in $A$ Theory of Justice. I will comment on this conception more fully in chapter VI below. 


\section{CHAPTER III}

\section{COMMUNITARIAN CRITIQUES: MICHAEL SANDEL AND CHARLES TAYLOR}

As 1 noted in the introduction, one of the most persistent lines of critique of Rawlsian liberalism has come from a group of thinkers loosely described as "communitarians." Two of the more important writers in this group are Michael Sandel and Charles Taylor. ${ }^{1}$ Many would include Alasdair Maclntyre in this group as well, since he shares some of the same concerns as the communitarians. But Maclntyre diverges from mainstream communitarians in a number of ways. Particularly, where Sandel and Taylor approach their discussion of liberalism and the self it presumes from a Hegelian point of view, Maclntyre is a self-professed neo-Aristotelian. Therefore, I will postpone my exegesis of Maclntyre until the next chapter.

Quite generally, communitarians "...question the claim for the priority of the right over the good, and the picture of the freelychoosing individual it embodies."2 Regarding the defects of the liberal self, communitarians maintain that liberals "...[fail] to

${ }^{1}$ Allen E. Buchanan, "Assessing the Communitarian Critique of Liberalism," Ethics, v. 99 \#4 (July 1989), p. 852 (footnote omitted).

2Michael Sandel, "Introduction," Liberalism and its Critics (New York: New York University Press, 1984), p. 5. 
recognize that the self is 'embedded' in and partly constituted by communal commitments and values which are not objects of choice." 3 By misunderstanding the way in which we are situated in a culture, communitarians hold that the liberal self is impoverished, insufficient, incoherent, or a combination of these. 4

Michael Sandel has noted that Rawls sees the self as prior to the ends which it chooses, 5 and thus:

The [liberal] priority of the self over its ends means I am never defined by my aims and attachments, but always capable of standing back to survey and assess and possibly to revise them. This is what it means to be a free and independent self, capable of choice...[However, communitarians]

say we cannot conceive of ourselves as independent in this way, as bearers of selves wholly detached from our aims and attachments. They say that certain of our roles are partly constitutive of the persons we are...But if we are partly defined by the communities we inhabit, then we must also be implicated in the purposes and ends characteristic of those communities. 6

${ }^{3}$ Buchanan, "Assessing the Communitarian Critique of Liberalism," p. 853.

${ }^{4}$ These three criticisms of liberalism in general are discussed by Alfonso J. Damico, "Introduction," Liberals on Liberalism (Totowa NJ: Rowman and Littlefield, 1986), p. 1.

${ }^{5} \mathrm{Cf}$. Rawls's remark in $T J$ that "[t]he self is prior to the ends which are affirmed by it; even a dominant end must be chosen from among numerous possibilities," (TJ, p. 3-4).

6Sandel, "Introduction," p. 5-6. 
Communitarians have argued that Rawls and Rawlsian liberals, by focusing on a conception of a person which is an impoverished, individual chooser of ends, have "...failed to account for those values of community, tradition, social solidarity, compassion and nurture, virtue, or moral responsibility which...represent the best hope for modern Western society." 7

In this chapter I examine the communitarian critique of the Rawlsian conception of the person. Sandel has given the most direct communitarian critique of Rawls's idea of the self, particularly in Liberalism and the Limits of Justice 8 Charles Taylor, however, has often cast the communitarian/liberal colloquy in terms analogous to the debate between Hegelians and Kantians. Since Rawls himself claims to be influenced by Kant, Taylor's criticisms of the liberal self generally can provide an additional perspective on this question.

\section{MICHAEL SANDEL'S CRITIQUE OF THE RAWLSIAN SELF}

Michael Sandel begins Liberalism and the Limits of Justice (hereafter $L L J$ ) by observing the Kantian roots of Rawls's conception of the self. He notes the difficulties with the allegedly "disembodied, transcendental" Kantian self, and claims that Rawls is trying to have "...liberal politics without [the] metaphysical

7Gerald Doppelt, "Is Rawls's Kantian Liberalism Coherent and Defensible?", Ethics, v. 99 \#4, (July 1989), p. 815.

${ }^{8}$ Michael Sandel, Liberalism and the Limits of Justice (Cambridge: Cambridge University Press, 1982). 
embarrassment..." of Kant's conception of the person. ${ }^{9}$ Sandel argues that ultimately, Rawls does not succeed:
Deontology...either fails as deontology or recreates in the original position the disembodied subject it resolves to avoid. Justice cannot be primary in the deontological sense, because we cannot coherently regard ourselves as the kind of beings the [Rawlsian deontological] ethic requires us to be. 10

Gerald Doppelt believes the skeleton of LLJ can be presented as a series of claims. ${ }^{11}$ I will use the portions of this skeleton that relate to the Rawlsian self as a superstructure for my discussion of Sandel. Except where noted, however, the specific details are mine.

\section{THE ANTECEDENTLY INDIVIDUATED SELF}

Sandel holds that the primary unit of justice as fairness is the individual:

[According to Rawls w]e are distinct individuals first and then (circumstances permitting) we form relationships and engage in co-operative arrangements with others. The point is not that persons co-operate out of selfish motives alone, but rather that our knowledge of the basis of plurality is given prior to experience, while our knowledge of

9 LLJ, p. 14.
10 LLJ, p. 14.

11 In Ethics, v. $99 \# 4$, July 1989, p. 815-851. 
the basis of unity or co-operation can only come in the light of experience.12

The Rawlsian self, then, is quintessentially, antecedently, individual. Communal aspects are not part of the core of what it is to be a person in the original position. Sandel observes that, in fact, Rawls wishes to keep communal presumptions out of the original position:

...we want to account for the social values, for the intrinsic good of institutional, community, and associative activities, by a conception of justice that in its theoretical base is individualistic. For reasons of clarity among others, we do not want to...suppose that society is an organic whole with a life of its own distinct from and superior to that of all its members in their relations with one another. Thus the contractual conception of the original position is worked out first. It is reasonably simple and the problem of rational choice that it poses is relatively precise. From this conception, however individualistic it might seem, we must eventually explain the value of community. 13

For Sandel, communal aspects of the person are contingent and chosen, as we shall see below.

$12 L L J$, p. 53.

$13 T J, \quad$ p. $264-265$ 


\section{THE SELF AS A CHOOSER OF ITS ENDS}

Sandel sees the Rawlsian person's relationship to its ends as a key aspect of Rawls's conception of the self. Sandel notes that Rawls wishes to avoid the isolation of the self in a Kantian, noumenal realm:

In Rawls' view, any account of self and ends must tell us not one thing but two things: how the self is distinguished from its ends, and also how the self is connected to its ends. Without the first we are left with a radically situated subject; without the second, a radically disembodied subject. 14

He describes Rawls's approach to this problem as follows.

Sandel asserts that the assumption of mutual disinterest is an epistomological, rather than a motivational (or psychological), claim about the possibility of self-knowledge: “...Rawls' assumption of mutual disinterest holds that all interests must be the interests of some subject [e.g., of a self]."15 Thus, the ends that a self has are essentially objects of possession. 16 Conceiving of ends in this way is to say that

... I am related to it [an end] in a certain wayit is mine rather than yours - and also that 1 am distanced from it in a certain way-that it

$$
\begin{aligned}
& 14 \text { LLJ, p. } 54 . \\
& 15 L L J, \quad \text { p. } 54 .
\end{aligned}
$$

$16 L L J$, p. 54. Sandel uses a parallel construction that is substantively identical, saying that the self is a subject of possession. Therefore, its ends are objects of possession. 
is mine rather than me. This latter point means that if I lose a thing I possess, I am still the same ' $I$ ' who had it... This distancing aspect is essential to the continuity of the [deontological] self [emphasis in original]. ${ }^{17}$

But how does the self come to possess these ends? Sandel posits two possibilities for human agency (i.e., the "...faculty by which the self comes by its ends"18), which he refers to as voluntarist and cognitive dimensions. ${ }^{19}$ in the former, agency is a function of personal choice; in the latter, it is a function of personal discovery. Sandel's discussion of these types of agency is given in terms of how each might repair "...a different kind of dispossession," dispossession being the condition in which the self is detached or undifferentiated from its ends. 20

If a self is detached from its ends, the remedy is the voluntarist sense of agency: "The [voluntarist sense of] agency involves the exercise of will, for it is the will that is able to transcend the space between the subject and its object without requiring that it be closed."21

But if a self is dispossessed because it is undifferentiated from its ends,
$17 L L J, \quad$ p. 55.
$18 L L J, \quad$ p. $57-58$.
$19 L L J$, p. 58.
$20 L L J$, p. 58.
$21 L L J, \quad$ p. 58. 
...dispossession is repaired by agency in its cognitive sense...since the subject achieves self-command not by choosing that which is already given (this would be unintelligible) but by reflecting on itself and inquiring into its constituent nature...22

However, Sandel has held that the Rawlsian self is antecedently given:

Where the subject is regarded as prior to its ends, self-knowledge is not a possibility in this sense, for the bounds it would define are taken as given in advance, unreflectively, by the principle of antecedent individuation. The bounds of the self are fixed and within them all is transparent. The relevant moral question is not 'Who am I?' (for the answer to this question is given in advance) but rather 'What ends shall I choose?' and this is a question addressed to the will.23

Since the bounds of the Rawlsian self are given, choice is the paradigm mode of agency, not reflection. For Sandel's reading of Rawls, the volitional aspect of a person is privileged over the cognitive:

The voluntarist notion of agency is thus a key ingredient in Rawls' conception, and plays a central role in the deontological ethic as a whole... The notion of a subject of possession, individuated in advance and given prior to its ends, seems just the conception required to redeem the deontological ethic

$22 L L J$, p. 58.

$23 L L J, \quad$ p. 58-59. 
without lapsing into transcendence. In this

way, the self is distinguished from its

ends...but it is also related to its ends, as

willing subject to the objects of choice.24

\section{THE INCOMPATIBILITY OF THE RAWLSIAN SELF WITH COGNITIVE ASPECTS}

Though Sandel believes the Rawlsian self is primarily characterized by its antecedent individuality and ability to choose, it remains to be seen if this conception is

...incompatible with...[Sandel's assertion] that

we can and do discover through critical selfreflection that there are certain normative ends or attachments essential to our identities, which in the first instance we do not choose but discover to be essential to us in this way. 25

According to Rawls, the claim of mutual disinterest (which

Sandel believes underlies the volitional aspect of the self) is a weak premise. As such, it does not rule out communal values:
Although justice as fairness begins by taking the persons in the original position as individuals...this is no obstacle to explicating the higher-order moral sentiments that serve to bind a community together. 26

Sandel thus interprets the Rawlsian conception of the self:

\section{LLJ, p. 59.}

25“Is Rawls's Kantian Liberalism Coherent and Defensible?", p. 817.

$26 T J$, p. 192, as quoted in LLJ, p. 61. 
All interests, values, and conceptions of the good are open to the Rawlsian self, so long as they can be cast as the interests of a subject individuated in advance and given prior to its ends, so long, that is, as they describe the objects I seek rather that the subject I am.

Only the bounds of the self are fixed in advance [italics in original]. 27

But for Sandel, it is exactly this sense in which the essence of the self is fixed that makes it incompatible with the cognitive aspect of agency. Since the self is fixed prior to experience, "...[n]o commitment could grip [the self] so deeply that [it] could not understand [it]self without it...."28 Sandel claims that

Rawls' account of how we choose would seem to confirm the limited scope for reflection on his conception. While...the conception of the good most appropriate to a particular person is said to be 'the outcome of careful reflection', it is clear that the objects of this reflection are restricted to (1) the various alternative plans and their likely consequences for the realization of the agent's desires, and (2) the agent's wants and desires themselves, and their relative intensities... The reflection involved in (2)...looks inward in a sense but not all the way in...Since for Rawls the faculty of selfreflection is limited to weighing the relative intensity of existing wants and desires, the deliberation it entails cannot inquire into the identity of the agent...Because this sort of deliberation is restricted to assessing the

$27 L L J, \quad$ p. 61-62.

$28 L L J, \quad$ p. 62. 
desires of a subject whose identity is given (unreflectively) in advance, it cannot lead to self-understanding in the strong sense which enables the agent to participate in the constitution of its identity. 29

Simple self-reflection (self-cognition) can only inform the Rawlsian self about what choices it has already made. Thus, on Sandel's reading, the Rawlsian "voluntarist" self is indeed incompatible with certain essential aspects that must be understood through selfreflection, not choice.

\section{THE VOLITIONAL ASPECT OF THE RAWLSIAN SELF AS INSUFFICIENT TOACCOUNT FOR COMMUNAL ENDS}

Sandel sees a basic flaw in Rawls's understanding of what a person is: "...Rawls' account rules out the possibility of what we might call 'intersubjective' or 'intrasubjective' forms of understanding, ways of conceiving the subject that do not assume its bounds to be given in advance." 30 An intersubjective conception of the self "...may embrace more than a single, individual human being, as when we attribute responsibility or affirm an obligation to a family or community... rather than to some particular human being." 31 The possibility of having an intersubjective conception of

\section{$29 L L J$, p. 159.}

$30 L L J$, p. 62. Sandel uses the word 'intersubjective' in a different sense than do many liberals.

${ }^{31} L L J, \quad$ p. 62-63. 
the self is essential for Sandel. For Sandel, part of what we are is determined by community:

On this strong view, to say that the members of a society are bound by a sense of community is not simply to say that a great many of them profess communitarian sentiments and pursue communitarian aims, but rather that they conceive their identitythe subject and not just the object of their feelings and aspirations-as defined to some extent by the community of which they are a part. For them, community describes not just what they have as fellow citizens but also what they are, not a relationship they choose (as in a voluntary association) but an attachment they discover, not merely an attribute but a constituent of their identity[emphasis in original]. 32

Sandel notes that Rawls explicitly rejects the conflation of individuals into a larger whole-remember the latter's claim that "[u]tilitarianism does not take seriously the distinction between persons."33 For Rawls, "[a]s a person's values and ends are always attributes and never constituents of the self, so a sense of community is only an attribute and never a constituent of a wellordered society."34 Thus, Sandel believes that Rawls misunderstands the constitutive nature of communal ends in our conception of the self.

$32 L L J, \quad$ p. 150.

${ }^{33}$ TJ, p. 27.

${ }^{34} L L J, \quad$ p. 64. 


\section{TAYLOR, HEGEL, AND PARTIAL COMMUNITIES}

Charles Taylor's philosophical writings have ranged widely, from questions of human agency, ${ }^{35}$ to the philosophy of social science, ${ }^{36}$ to the philosophy of language ${ }^{37}$ and many other topics. But he has also written extensively in the area of political philosophy, ${ }^{38}$ often developing his concerns about the individual self and its relationship to community.

In his commentary on Hegel, ${ }^{39}$ Taylor presents a communitarian critique of the liberal self in an interesting fashion. He develops ideas found in the writings of Hegel, particularly those

${ }^{35}$ See, e.g., "What is Human Agency," T. Mischel, ed., The Self (Oxford: Blackwell, 1977) p. 103-155.

${ }^{36}$ See, e.g., "Neutrality in political science," from P. Laslett and G. Runciman, eds., Philosophy, Politics and Society (Oxford: Blackwell, 1967) p. 25-57, and "Rationality," from Hollis and Lukes, eds., Rationality and Relativism (Oxford: Blackwell, 1982), p. 87105.

${ }^{37}$ See, e.g., "Language and Human Nature," in Charles Taylor, Human Agency and Language: Philosophical Papers I (Cambridge: Cambridge University Press, 1985) p. 215-257, and "Theories of Meaning," in Proceedings of the British Academy, 66 (1980) p. 283327.

${ }^{38}$ See e.g., Philosophy and the Human Sciences: Philosophical Papers II (Cambridge: Cambridge University Press, 1985), particularly section II, "Political Philosophy," p. 185-337.

${ }^{39}$ Charles Taylor, Hegel (Cambridge: Cambridge University Press, 1975). All citations from this text in this paper are from the excerpts entitled "Hegel: History and Politics" Liberalism and its Critics (these excerpts hereafter referred to as Hegel). 
which are in opposition to Kant, and uses them as a foundation for his own examination of the liberal concept of the person. Though Tayor does not directly mention Rawls in Hegel, his comments on Kant link up with Rawls's Kantian conception of the self.

\section{7. 'SITTLICHKEIT' AND 'MORALITÄT'}

Taylor describes Hegel's critique of the moral theory of Kant in terms of the differences between 'Sittlichkeit' and 'Moralität.' 'Sittlichkeit' is usually translated into English as 'ethical life' or 'concrete ethics.'40 In Hegel's special sense of Sittlichkeit, this term

...refers to the moral obligations I have to an ongoing community of which I am part...The crucial characteristic of 'Sittlichkeit' is that it enjoins us to bring about what already is...there is no gap between what ought to be and what is....41

This is the Hegelian concept of situated ethics.

The concept of 'Moralität' is different, however: "Here we have an obligation to realize something which does not exist...And connected with this, the obligation holds of me not in virtue of being part of a larger community life, but as an individual rational will."42 Taylor views Hegel as criticizing Kant for holding this view:

${ }^{40}$ Hegel, p. 177.

41 Hegel, p. 177-178.

42 Hegel, p. 178. 
Kant identifies ethical obligation with

Moralität, and cannot get beyond this. For he presents an abstract, formal notion of moral obligation, which holds of man as an individual, and which being defined in contrast to nature is in endless opposition to what is. ${ }^{43}$

Since morality is a purely formal notion, much like the Rawlsian concept of right, it has no substantive content. Remember that for Kant, "...the ground of [moral] obligation must be looked for, not in the nature of man nor in the circumstances of the world in which he is placed, but solely a priori in the concepts of pure reason...."44 But for Hegel, the community of which we are a part does provide a substantive content to morality. ${ }^{45}$ We cannot separate morality from community (i.e., "nature").

\section{THE COMMUNAL IDENTITY OF THE SELF}

In Taylor's reconstruction of Hegel, we have seen that the Kantian individual self is deficient because it cannot recognize the substantive moral content provided by community. Kant certainly sees community as part of the 'circumstances of the world in which man is placed,' mentioned above. Taylor notes the difficulty that the contemporary Western person may have in dealing with Hegelian

${ }^{43}$ Hegel, p. 178.

${ }^{44}$ Groundwork of the Metaphysic of Morals, p. 57.

${ }^{45}$ Hegel, p. 178. 
concepts like Volksgeist (roughly, 'communal spirit' or 'spirit of a people'). But "[t]hese ideas only appear mysterious because of the powerful hold on us of atomistic prejudices...."46 The pervasiveness of liberal individualistic assumptions has blinded us to certain aspects of what it means to be a self:

... when we think of a human being, we do not simply mean a living organism, but a being who can think, feel, decide, be moved, respond, enter into relations with others; and all this implies a language, a related set of ways of experiencing the world, of interpreting his feelings, understanding his relation to others, to the past the future, the absolute, and so on. It is the particular way he situates himself within this cultural world that we call his identity. 47

Taylor rejects the idea that culture is simply the contingent situation into which a group of antecedently individuated selves are placed. Instead,

...our experience is what it is, is shaped in part, by the way in which we interpret it; and this has a lot to do with the terms which are available to us in our culture...it is no extravagant proposition to say that we are what we are in virtue of participating in the larger life of our society....48

46 Hegel, p. 182.

47 Hegel, p. 182.

48 Hegel, p. 183. 
Taylor says that for Hegel, to live in a state with Sittlichkeit is to be free. The archetype ancient state for Hegel was the Athenian polis, "... where the norms and ends expressed in the public life of a society [were] the most important ones by which its members define[d] their identity as human beings."49 Hegel wants to fuse the ancient communal values with those of modern individualism, in a dialectical fashion. 50 The result of this process is the Hegelian concept of "absolute freedom"-that is, universal and total participation of free individuals within a true community. 51

Taylor notes that preliberal societies were characterized by an hierarchical order. Though liberals often see this order as merely an attempt to preserve the status quo, "...these conceptions also were the ground of men's identification with the society in which they lived." 52 But the rise of liberal moral subjectivity led to an instrumentalist conception of society: "Society was justified not by what it was or expressed, but by what it achieved, the fulfillment of men's needs, desires and purposes." 53 This has led western culture toward a crisis. Modern liberal humanity needs to remain

${ }^{49}$ Hegel, p. 185.

50This idea was made clear to me by Dr. Craig Carr.

51 Hegel, p. 191.

52 Hegel, p. 191.

${ }^{53} \mathrm{Hegel}$, p. 191. 
connected to its ends, or else alienation may result. Even liberals are heard to echo Donne's oft-quoted phrase, "no man is an island." But modern liberal theory "...has not provided a basis for men's identification with their society." 54

Taylor claims that absolute freedom, that is, total equal participation, is an effort by liberals to fill this void. But it cannot: "...absolute freedom requires homogeneity. It cannot brook differences which would prevent everyone participating totally in the decisions of the society." 55 This homogeneity is a result of trying to overcome alienation by institutionalizing participation, by "...creating a society in which everyone...participate[s] fully in the decisions." 56 In so doing, the smaller, "partial" communities that have given individuals their essential characteristics have been undermined. The conglomerative liberal state that has replaced these partial communities is unable to provide identity or stem alienation:

Thus Hegel's dilemma for modern democracy...is this: The modern ideology of equality and of total participation leads to a homogenization of society. This shakes men loose from their traditional communities, but cannot replace them as a focus of identity. Or rather, it can only replace them as such a focus under the impetus of militant nationalism or some totalitarian ideology

$54 \mathrm{Hegel}$, p. 191.

55 Hegel, p. 193.

56 Hegel, p. 194. 
which would depreciate or even crush diversity and individuality. 57

Certainly, Taylor does not consider nationalism or totalitarianism viable substitutes for partial communities.

\section{ATOMISM, FREEDOM, AND THE LIBERAL SELF}

In his article entitled "Atomism,"58 Taylor unpacks the concept of political atomism with the aim of explicating certain aspects of the liberal self. For Taylor, 'atomism' refers to:

...the doctrines of social contract theory and...successor doctrines which...inherited a vision of society as in some sense constituted by individuals for the fulfillment of ends which were primarily individual...The term is also applied to contemporary doctrines which hark back to social contract theory, or which try to defend in some sense the priority of the individual and his rights over society, or which present a purely instrumental view of society...The central doctrine of this tradition is an affirmation of what we could call the primacy of rights. ${ }^{59}$

\section{Hegel, p. 195.}

58"Atomism," in Philosophy and the Human Sciences: Philosophical Papers I/ (Cambridge: Cambridge University Press, 1985), p. $187-210$.

59“Atomism," p. 187-188. 
Though Robert Nozick's libertarian conception of the self in Anarchy, State and Utopia 60 is Taylor's named target in this article, the criticisms are equally germane to Rawls's conception of the self.

\section{THE SITUATEDNESS OF RIGHTS}

Taylor begins by noting that in many liberal theories, the rights of the individual are given without argument, that is, a priori:

...the starting point in individual rights has an undeniable prima facie force for us... Why do we even find it reasonable to start a political theory with an assertion of individual rights and to give these primacy? I want to argue that the answer to this question lies in the hold on us of what I have called atomism. Atomism represents a view about human nature and the human condition which (among other things) makes a doctrine of the primacy of rights plausible...atomism affirms the self-sufficiency of man alone or, if you prefer, of the individual. 61

Now of course Rawls would deny that his theory entails any specific view about human nature. Remember that Rawls believes that his principles of justice are (Kantian) categorical imperatives.62 And

60Robert Nozick, Anarchy, State and Utopia (Boston: Oxford University Press, 1974).

61"Atomism," p. 189.

62 TJ, p. 253. I have noted above (in chapter II, $\S 5$ ) that several aspects of Rawls's theory are not actually Kantian. For a more through discussion of this point, see Otfried Höffe, "Is Rawls' Theory of Justice really Kantian?" 
Kant himself says that "...the ground of [moral] obligation must be looked for, not in the nature of man nor in the circumstances of the world in which he is placed, but solely a priori in the concepts of pure reason...."63 Additionally, Rawls would jeopardize the priority of the right (a purely formal notion) over the good if he were to make contestable claims about human nature as part of the principle of right.

But for Taylor, atomism itself is a situated concept. We cannot know what it means to be self-sufficient without a cultural context, that is, without knowledge of 'the nature of man or of the circumstances in which he is placed.' As Taylor notes, Aristotle believed that "[m]an is a social animal, indeed a political animal, because he is not self-sufficient alone, and in an important sense is not self-sufficient outside a polis." 64 This does not mean merely that humans could not survive outside of society, though arguably most would not. Rather, it is that we would not really be human outside of society:

...living in society is a necessary condition of the development of rationality...or of becoming a moral agent in the full sense of the term, or of becoming a fully responsible, autonomous being...From the standpoint of this thesis, too, it is irrelevant whether an organism born from a human womb would go on living in the wilderness; what is important

${ }^{63}$ Groundwork of the Metaphysic of Morals, p. 57.

64"Atomism," p. 189. 
is that this organism could not realize its specifically human potential. 65

Someone with individualist presuppositions might argue that all this talk of 'human potential' or 'capacity to be human' is irrelevant:66 "Plainly [the individualist might say], in our ordinary attribution of rights, we accord them to human beings as such, quite regardless of whether they have developed such potential or not." 67

However, Taylor believes that this individualist is misunderstanding what it means to have a right. We attribute rights to beings because

...these beings exhibit a capacity which commands respect, which capacity helps determine the shape of the rights, or what the rights are rights to. Once we accept that beings with this capacity command respect...it is sufficient that we identify $A$ as possessing this capacity to make $A$ a bearer of rights. 68

Though we may respect animals or other life-forms, humans have more rights than animals because we value and respect human capacities more:69

65"Atomism," p. 191.

66"Atomism," p. 191.

67"Atomism," p. 191.

68"Atomism," p. 192.

69"Atomism," p. 193. I recognize that the relative value of human capacities is a contested point, but this is irrelevant to the argument. 
Beings with these [human] capacities command our respect, because these capacities are of special significance for us; they have a special moral status...In other words, our conception of the specifically human is not at all irrelevant to our ascription of rights to people. On the contrary, there would be something incoherent and incomprehensible in a position which claimed to ascribe rights to men but which disclaimed any conviction about the special moral status of any human capacities whatever and which denied that they had any value or worth. 70

On Taylor's view, then, the concept of what it means to accord something a right is situated in a culture. This notion is bound up with the idea that we give rights to human beings precisely because of a 'conviction about the special moral status of human capacities.' Underlying what appears to be a "neutral" claim about human rights is a concept of the self: "...the doctrine of the primacy of rights is not as independent as its proponents want to claim from considerations about human nature and the human social condition."71

\section{RIGHTS AND THE OBLIGATION TO BELONG}

Taylor sees rights as invoking value-judgements about human nature and human capacity. More specifically,

70"Atomism," p. 193 (note omitted).

71 “Atomism," p. 197. 
To affirm the worth of the human capacity to form moral and religious convictions goes far beyond the assertion of the right to one's convictions. It also says that I ought to become the kind of agent who is capable of authentic conviction, that I ought to be true to my own convictions and not live a lie or a self-delusion out of fear or for favour, that 1 ought in certain circumstances to help foster this capacity in others... This is because we are dealing with a characteristically human capacity...to affirm [a] right [of being $A$ ] is to say that a creature such as $A$ lays a moral claim on us not to interfere. It thus also asserts something about $A$ : $A$ is such that this injunction is somehow inescapable. 72

Recall Taylor's thesis that men and women cannot realize human capacities (e.g., the capacity to choose independent moral convictions) outside of society ( $\S 11$ above). Taylor argues that

...we cannot in the face of this social thesis go on to assert the primacy of rights, that is, claim that we are not under obligation 'by nature' to belong to and sustain a society of the relevant type...asserting rights itself involves acknowledging an obligation to belong [to the relevant society]. ${ }^{73}$

This is because according to Taylor, "individual" rights cannot exist outside of society.

It should be clear at this point that Rawls himself would not agree that his theory is atomistic. He has attempted to keep substantive notions about human nature out of the principles of right

72“Atomism," p. 194-195.

73"Atomism," p. 198-200. 
in justice as fairness. But it is also clear that justice as fairness uses an individualistic conception of the self in the original position to derive the principles of justice. Since the individual is the bearer of rights in this theory, its rights are primary (or prior) to conglomerative bodies such as the state, social groups, and so on. It is individuals who are exercising autonomy and acting according to their moral nature by forming a social union of social unions.

Taylor argues that individualism or atomism, far from being a purely formal principle that may be accepted a priori, encompasses substantive claims about what it is to be a self. Further, he argues that if we accept atomism, we must understand it as a societally embedded concept. This provides us with a duty to belong to the relevant culture.

\section{COMMUNITARIANS AND THE SITUATED SELF}

Though Sandel and Taylor differ in their approaches to criticizing liberalism, there is a common thread that runs through the communitarian argument. This thread is the critique of the liberal individual self.

According to the communitarians, Rawls makes several fundamentally specious assumptions about what it is to be a self. First, Rawls's conception of the self is overly individualistic. It is antecedently separate from other selves, which follows from the assumption of mutual disinterest. This individuation skews the 
outcome of the original position towards principles that favor the individual as opposed to other groups. Sandel has argued that

...we are neither as transparent to ourselves nor as opaque to others as Rawls' moral epistemology requires. If our agency is to consist in something more than the exercise in 'efficient administration' which Rawls' account implies, we must be capable of a deeper introspection than a 'direct selfknowledge of our immediate wants and desires allows. but to be capable of a more thoroughgoing reflection, we cannot be...individuated in advance and given prior to our ends... 74

Rawls also overvalues the ability of the self to choose its own ends and conceptions of the good. Since we are situated beings, our capacity for self-understanding is at least as important in determining identity as is our capacity for choice. Rawls's understanding of persons as essentially volitional closes off essential corridors in the search for identity. We cannot look merely inward to determine what we are. We must also look outward to the culture of which we are a part. To discount this situated aspect of ourselves is to misunderstand and undervalue our shared, communal ends.

On the communitarian argument, liberalism's attempts to artificially induce societal cohesion, by instituting radical equality and participation, are bound to fail. The liberal conglomerative state is not built upon organic groups, but instead is composed of 
artificially individuated selves. This has produced a lessening of communal values deemed essential for persons, and has led to totalitarianism and hyper-nationalism. These last two conditions ultimately devalue and destroy the very individual self that liberals such as Rawls have attempted to preserve.

Rawls has, of course, responded to these criticisms in some depth. In chapter $V$, I will examine his rejoinder to the communitarian critique. 


\section{CHAPTER IV}

\section{ALASDAIR MACINTYRE AND THE NEO-ARISTOTELIAN CRITIQUE}

Alasdair Maclntyre's wide-ranging criticism of modernity has usually been aimed at a larger target than just the liberal concept of a self. The title of his best-known book After Virtue 1 suggests that our entire (liberal) culture may be past the point where traditional solutions to social problems can be recaptured.2

But Macintyre does have much to say about the concept of a self, and his comments converge in several places with those of the communitarians mentioned above. I will discuss this in the end of this chapter. The elemental differences between Maclntyre and the mainstream communitarians can be seen in two comparisons. First, where communitarians such as Sandel and Taylor approach the liberal self essentially from the Hegelian sense of situated ethics, Macintyre holds that the liberal self is deficient because it cannot recapture a sense of Aristotelian virtue ( $\mid$ will explain the latter

${ }^{1}$ Alasdair Macintyre, After Virtue 2nd. ed.,(South Bend IN: University of Notre Dame Press, 1984).

2Though Macintyre has developed this idea in his more recent work, Whose Justice? Which Rationality? (South Bend IN: University of Notre Dame Press, 1988), his commentary on the liberal self is most perspicuously presented in After Virtue. Therefore, I will concentrate my discussion on the latter text. 
concept below). And while Sandel and Taylor place their emphasis upon cultural or social situatedness, Maclntyre is much more concerned with the self in a "temporal" community. Though Macintyre diverges from the mainstream communitarian critique in several key areas, even these arguments bear an analogous relationship to those of the communitarians. I will discuss these connections at the end of this chapter.

Macintyre pictures the self as located in a continuing "narrative." Thus, we are not only situated in a culture, as Taylor holds, but we are also situated in a type of "story." Just as a story contains a temporal element, a beginning, middle, and end, the narrative or narratives that constitute our existence situate us in time.

\section{THE SEARCH FOR THE UNITY OF THE SELF}

Macintyre's concept of the search for a "unity of the self" is a quest for what a psychologist might call personal identity. A self with no unity is incongruent with our understanding of what it is to be a person. If a person has no continuity from one moment to the next, that is, if we cannot identify a set of actions as being performed by a single being, we must be misunderstanding what it is that is the "cause" of these actions.

For Macintyre,

...the unity of a human life becomes invisible to us when a sharp separation is made either between the individual and the roles that he 
or she plays...or between the different role-

and quasi-role-enactments of an individual

life so that life comes to appear as nothing

but a series of unconnected episodes-a

liquidation of the self characteristic.... ${ }^{3}$

The problem that arises when we demarcate our "selves" from the roles that we play is central to the thesis of After Virtue.

Individual selves, strongly differentiated (and presumably prior) to societal roles, are unable to “...exercise...dispositions which could genuinely be accounted virtues...."4 Maclntyre's concept of an "Aristotelian virtue" entails not merely the skill of dealing effectively with certain situations, like a job or a personal relationship, but of genuinely possessing a trait that is displayed in manifestly different situations. An (expectably classical) example that Maclntyre gives is that of Hector, who "...exhibited one and the same courage in his parting from Andromache and on the battlefield with Achilles..."5 For Maclntyre's conception, a role is not something that we inhabit only as the need arises, ready to be sloughed off when no longer appropriate. It is a constitutive part of our "self."

This separation between the role and the self, which Maclntyre believes exists in modern liberal culture, indicates an impoverished concept of the person. According to Maclntyre, we cannot be

${ }^{3}$ After Virtue, p. 204.

${ }^{4}$ After Virtue, p. 205.

${ }^{5}$ After Virtue, p. 205. 
separated from the roles that we play. These roles are part of what he refers to as the "narrative concept of the self."

\section{THE NARRATIVE CONCEPT OF THE SELF}

Maclntyre observes that it is a "...conceptual

commonplace...that one and the same segment of human behavior may be correctly characterized in a number of different ways."6 For example, it is reasonable to describe the activity that I am pursuing at this moment (I will call it activity $X$ ) variously as typing, wordprocessing, writing my paper, completing my Master's degree or increasing my understanding of this topic. In order to make these descriptions intelligible, however, they must be made in reference to both causal (or intentional) and temporal aspects. As regards the former, it would be unintelligible to claim that activity $X$ would be best understood as an attempt to score a home-run in the 1969 World Series. There is no evidence that this is what $I$ intend to bring about by pursuing activity $X$. This account fails to explain my intentions in pursuing activity $X$.

To understand the temporal aspects of activity $X$, we must appreciate that it is an action in a sequence. It would make no sense for someone without my "history" to be pursuing activity $X$ as described above. It is unlikely that anyone who has not pursued the usual educational steps that precede the writing of a thesis would

${ }^{6}$ After Virtue, p. 206. 
be writing one. ${ }^{7}$ Remember my original characterizations of activity $X$ : typing, word-processing, writing a paper, completing a Master's degree or increasing my understanding of this topic. Notice generally that as they increase in what we might call scope, they also provide a relatively more complete understanding of the self that is doing activity $X$. At first, we see someone who can type, next someone who can use a computer, then a person who is capable of "writing," next a Master's candidate, and finally an individual who is pursuing knowledge as part of a general plan of life.

Thus, Maclntyre believes that we are imbedded in "...a concept of a self whose unity resides in the unity of a narrative which links birth to life to death as narrative beginning to middle to end." 8 This does not imply that a single narrative is sufficient to understand a human life. Just as we may have internally conflicting and competing desires, we may be parts of a number of interlocking stories. For instance, another possible characterization of activity $X$ might be 'providing light reading for my thesis committee.' This description understands activity $X$ from within the narrative of another self.

But if our life is a story,

7 Indeed, insofar as a baccalaureate degree and graduate-level classwork are required prerequisites for the writing of a Master's thesis, it is impossible that anyone without this "history" could write one.

${ }^{8}$ After Virtue, p. 205. 
...we are never more (and sometimes less)

than the co-authors of our own

narratives...We enter upon a stage which we

did not design and we find ourselves part of

an action that was not of our making. Each of

us being a main character in his own drama

plays subordinate parts in the dramas of

others, and each drama constrains the others. ${ }^{9}$

It is here that we can see Maclntyre's similarity to the communitarians. Othello seen apart from the racial attitudes of Venice or the treachery of lago would hardly be the tragic figure that we know from Shakespeare. But is it possible that the "essence" of Othello could be transplanted to the court of Denmark or Scotland, and thus have different characteristics, but still be the same "self?" No-we would then have Hamlet or Macbeth, whom Maclntyre would argue are two selves entirely different and separate from the jealous moor. What we are is determined both by the narrative of which we are a part, and the intersection of ours with other's narratives.

\section{TELEOLOGY AND THE NARRATIVE SELF}

Since our narratives do combine both with other person's and with natural circumstances over which we have limited control, "...at any given point in an enacted dramatic narrative we do not

${ }^{9}$ After Virtue, p. 213. 
know what will happen next."10 But there is another aspect of our narrative lives, and this is "...a certain teleological character:"1 1
We live out our lives, both individually and in our relationships with each other, in the light of certain conceptions of a possible shared future... There is no present which is not informed by some image of some future and an image of the future which always presents itself in the form of a telos -or of a variety of ends or goals-towards which we are either moving or failing to move in the present. 12

Of course it is true that not all persons will have a telos. For Macintyre, persons who complain that
...life is meaningless...as do some of those who attempt or commit suicide...he or she is often and perhaps characteristically complaining that the narrative of their life has become unintelligible to them, that it lacks any point, any movement toward a climax or a telos. 13

These two characteristics, unpredictability and a type of teleology, coexist in any one self, according to Macintyre.

We have seen how Maclntyre rejects the idea of a self that is independent from its narrative: “...all attempts to elucidate the notion of personal identity independently of and in isolation from
10 After Virtue, p. 215.
11 After Virtue, p. 215.
12 After Virtue, p. 215-216.
${ }^{13}$ After Virtue, p. 217. 
the notions of narrative, intelligibility and accountability are bound to fail. As all such attempts have."14 I will show below that Macintyre also rejects the idea that a self is able to choose a good only as an individual.

\section{THE GOOD, AND THE SENSE OF A TRADITION}

Maclntyre understands the quest for unity of a self as finding its answer in the idea of a self situated in a narrative. And thus, ...to ask 'What is the good for me?' is to ask how best I might live out that unity and bring it to completion. To ask 'What is the good for man?' is to ask what all answers to the former question must have in common. ${ }^{15}$

As Macintyre has claimed, we must have at least some idea of what our telos is in order to search for it. But it is not necessary, and indeed not desirable, that the good be specified in advance of the search. It is at least partially the search for our telos, "...through encountering and coping with... various particular harms, dangers, temptations and distractions...,"16 that we determine our idea of our good.

However, this cannot be done in a vacuum, on an island, as it were. The struggle mentioned above is at least partially embedded.

\footnotetext{
${ }^{14}$ After Virtue, p. 218.

${ }^{15}$ After Virtue, p. 218-219.

${ }^{16}$ After Virtue, p. 219.
} 
And thus the idea of a good must, according to Maclntyre, be situated in a society:

For I am never able to seek for the good...qua individual. This is partly because what it is to live the good life concretely varies from circumstance to circumstance even when it is the same conception of the good life and one and the same set of virtues which are being embodied in a human life...we all approach our own circumstances as bearers of a particular social identity... what is good for me has to be the good for one who inhabits these roles... These constitute the given of my life, my moral starting point. 17

Macintyre notes that this conception does not square with the modern liberal conception of the individual person. The liberal self chooses what it will be, and what its ends are. This "detachable self" contrasts strongly with the narratively situated self:

For the story of my life is always embedded in the story of those communities from which I derive my identity. I am born with a past; and to try to cut myself off from that past, in the individualist mode, is to deform my present relationships. ${ }^{18}$

This "past" is our sense of tradition. Maclntyre's sense of this term is to be distinguished, however, from the Burkean concept of tradition. Macintyre rejects Burke's contrast of “...tradition with reason and the stability of tradition with conflict." 19 Maclntyre

${ }^{17}$ After Virtue, p. 220.

${ }^{18}$ After Virtue, p. 221.

${ }^{19}$ After Virtue, p. 221-222. 
notes that reason itself is situated within a tradition. $20 \mathrm{He}$ also claims that "[m]oreover when a tradition is in good order it is always partially constituted by an argument about the goods the pursuit of which gives to that tradition its particular point and purpose."21 But of course Maclntyre sees both the notions of an 'argument' and a 'tradition' as situated in a community.

\section{MACINTYRE AS A NEO-ARISTOTELIAN COMMUNITARIAN}

Though I doubt that Maclntyre himself would approve of this title, he is best characterized as an anti-modernist conservative.

Not a conservative in the reactionary or Burkean sense, however, but instead with the classic meaning of wishing to 'conserve' a tradition.

For Macintyre, the paradigm community was the Athenian polis. But of course the circumstances of the polis have been irretrievably erased by over two centuries of change, and the 'communities' that liberal culture has substituted for it are unsatisfactory. Maclntyre sees humanity in the difficult position of being 'after [Aristotelian] virtue.' Though Maclntyre seems to be dubious of modernity's chances in a larger sense, it is his concept of narrative situatedness

20Peter Winch espouses a similar idea in "Understanding a Primitive Society," American Philosophical Quarterly, 1 (1964), pp. 307-24, reprinted in B.R. Wilson (ed.) Rationality.

${ }^{21}$ After Virtue, p. 222. 
that allows us to associate him with mainstream communitarians such as Sandel and Taylor. 


\section{CHAPTER V}

RAWLS'S REJOINDER: TOWARDS A POLITICAL CONCEPTION OF THE SELF

As I observed in chapter I of this paper, the reaction to $A$ Theory of Justice has been immense.1 In response to his critics, and as a result of his own ongoing evaluation of justice as fairness, Rawis has published a continuing series of articles devoted primarily to the explication and amplification of the ideas found in TJ. 2

1 For a partial bibliography of the response to Rawls, see Norman Daniels's "Preface" to the new edition of Reading Rawls.

In Ethics 99 (July 1989) Richard Arneson gives the following selected listing of Rawls's articles since $T J$ : "The Independence of Moral Theory," Proceedings and Addresses of the American Philosophical Association 48 (1974): 5-22; "A Kantian Conception of Equality,": Cambridge Review 96 (1975): 94-99, reprinted as "A Well-Ordered Society," in Philosophy, Politics, and Society, ed. Peter Laslett and James Fishkin, 5th ser. (New Haven Conn.: Yale University Press, 1979); "Fairness to Goodness,"Philosophical Review 84 (1975): 536-54; "The Basic Structure as Subject," in Values and Morals, ed. Alvin Goldman and Jaegwon Kim (Dordrecht: Reidel, 1978), pp. 47-71; "Kantian Constructivism in Moral Theory: The Dewey Lectures 1980," Journal of Philosophy 77 (1980): 51572; "The Basic Liberties and Their priority,": in The Tanner Lectures on Human Values, vol. 3, ed. Sterling McMurrin (Salt Lake City: University of Utah Press, 1982); "Social Unity and Primary Goods,": in Utilitarianism and Beyond, ed. Amaryta Sen and Bernard Williams (Cambridge: Cambridge University Press, 1982), pp. 159-85; "Justice as Fairness: Political not Metaphysical,": Philosophy and Public Affairs 14 (1985): 223-51; "The Idea of an Overlapping 
I will argue in this chapter that Rawls has responded to communitarian critiques of his concept of the self in the following ways. First, Rawls has shifted the emphasis of his work from a type of universal moral theory to a more local political one: "Rawls is no longer engaged in an attempt to identify and justify principles of justice for all human societies at all times and to any rational person whatsoever." 3 Rather, justice as fairness is meant to apply to societies in the western political tradition. Associated with this idea is the Kantian conception of the person:

The justification of the principles chosen in the original position is relativized to [the Kantian] ideal of the person and thereby to modern democratic culture in which, Rawls asserts, this ideal informs each citizen's ordinary understanding of herself at least in her relationship to the public order. ${ }^{4}$

For Rawls, the Kantian self represents "...a conception of the person implicitly affirmed in [our] culture, or else one that would prove acceptable to citizens once it was properly presented and explained." 5

Consensus," Oxford Journal of Legal Studies 7 (1987): 1-25; and "The Priority of Right and Ideas of the Good," Philosophy and Public Affairs 17 (1988): 251-76. p. 696.

3Richard Arneson, "Introduction." Ethics v. 99 \#4 (July 1989),

${ }^{4}$ Richard Arneson, "Introduction," p. 696.

5John Rawls, "Kantian Constructivism in Moral Theory: The Dewey Lectures 1980," Journal of Philosophy 77 (1980), p. 518. 
As Richard Arneson observes, Rawls has denied that "...justice as fairness presupposes any particular controversial metaphysics of the self." 6 Rawls does not reject the idea that a concept of the person may be found in justice as fairness, as the notion of a Kantian self implies. But he claims that this conception belongs to the political realm only, and does not presume any private idea of the person. This self is 'political, not metaphysical.'

Finally, Rawls has developed the idea of an "overlapping consensus." 7 According to Rawis, this is

...a regulative political conception of justice that can articulate and order in a principled way the political ideals and values of a democratic regime, thereby specifying the aims the constitution is to achieve and the limits it must respect. 8

With this concept, Rawls continues the shift of the focus of his work from the 'metaphysical' to the 'political.'

\section{KANTIAN CONSTRUCTIVISM}

In April, 1980, Rawls presented a series of three talks on "Kantian Constructivism in Moral Theory" as the fourth series of

6Richard Arneson, "Introduction," p. 704.

7See John Rawls, "The Idea of an Overlapping Consensus," Oxford Journal of Legal Studies 7 (1987), p.1-25 (hereafter referred to as "Overlapping Consensus").

8"Overlapping Consensus," p. 1. 
John Dewey lectures at Columbia University. ${ }^{9}$ Though nothing in these lectures radically broke with the discussion of justice as fairness in $T J$, several amendments and shifts of emphasis from $T J$ are present, as I will note below. These changes represent the beginnings of Rawls's movement towards a more "political" conception.

Rawls describes the basic idea of Kantian constructivism as follows:

... [Kantian constructivism] specifies a particular conception of the person as an element in a reasonable procedure of construction, the outcome of which determines the content of the first principles of justice... The leading idea is to establish a suitable connection between a particular conception of the person and first principles of justice, by means of a procedure of construction. ${ }^{10}$

Given the fact that "...there is no agreement on the way basic social institutions should be arranged if they are to conform to the freedom and equality of citizens as moral persons...,"11 we must justify a conception of justice "...that is (most) reasonable for

9These were published as "Kantian Constructivism in Moral Theory: The Dewey Lectures 1980," Journal of Philosophy 77 (1980): p. 515-572. These published versions hereafter will be referred to as "Kantian Constructivism".

10"Kantian Constructivism," p. 516.

11 "Kantian Constructivism," p. 517. 
[citizens] in virtue of how they conceive of their persons...."12

Kantian constructivism is thus a justificatory scheme for establishing principles of justice for a certain (Kantian) conception of persons.

Rawls's attempt to distance himself from universalist aspirations can be seen here. The purpose of Kantian constructivism is not to establish objective moral truths, but to find a charter that can serve as a basis for social cooperation:

Kantian constructivism holds that moral objectivity is to be understood in terms of a suitably constructed social point of view that all can accept. Apart from the procedure of constructing the principles of justice, there are no moral facts [emphasis added]. ${ }^{13}$

But there are moral facts in this conception, although Rawls does not identify them as such. The Kantian idea of a person is given a priori, and is used to construct principles of justice. Since this Kantian self is a premise of the argument that Rawls makes for justice as fairness, it is not a subject for discussion in the process of constructivism. It is the nature of a premise of an argument that it is accepted as a "fact," that is, that it is agreed that its truth is not immediately at issue. It is the argument from accepted premises that is being directly considered, in this case, the process of constructivism.

12“Kantian Constructivism," p. 517.

13“Kantian Constructivism," p. 519. 
However, if we cannot agree on premises to begin with, we can have no reasonable argument. Two geometers, one Euclidean and one non-Euclidean, cannot discuss "geometry." Each holds a different set of premises about points, planes, and curves, which may be mutually exclusive. They may argue about the validity of each other's premises. But unless they can find commonly shared "facts" about geometry that serve as premises, each individual's proofs will likely not hold for the other.

In the process of Kantian constructivism, Rawls assumes that his Kantian conception of the self is an uncontroversial premise, which can be widely accepted in this culture. In doing so, he wishes to carry on an argument analogous to one that might be had between two Euclidean geometers, who have already agreed upon a set of shared initial "facts." It is not immediately obvious, however, that the Kantian conception of the self is as uncontroversial as he believes. If it is to serve as a basis for the justification of liberal principles of justice, Rawls must show that this self is either overwhelmingly accepted in our culture, or that it is substantively neutral between various conceptions of the good. The former condition is unlikely, given Rawls's assumption of pluralism. In chapter VI below, I will examine the possibility of the latter condition holding. 


\section{THE KANTIAN SELF}

The Kantian self coincides in many places with the concept of self described in $T J$. Persons are thought of as free and equal moral persons. But Rawls has expanded his description of "moral persons" in important ways. They still have the moral capacities of possessing a sense of justice and the ability to form and pursue a conception of the good. However, Rawls has added two corresponding "...highest-order interests [of moral persons] to realize and exercise these powers...these interests govern deliberation and conduct." 14 The result of this change is that moral persons will now select "...what is to count as primary goods within the framework of [these] model-conceptions [italics added]."15 They will choose goods that "...are necessary as social conditions and allpurpose means to enable human beings to realize and exercise their moral powers and to pursue their final ends...."16

Here, Rawls appears to be making a minor concession to communitarian criticisms of the mutually disinterested aspect of persons in $T J$. By acting according to these 'highest-order interests,' persons will make choices of primary goods that ensure that all persons in a culture can be autonomous moral beings, rather than goods that will only serve an individual's narrow self-interest.

14"Kantian Constructivism," p. 525.

15“Kantian Constructivism," p. 526-527.

16"Kantian Constructivism," p. 526. 
Once again, however, Rawls has failed to argue a case for these characteristics. They are simply posited a priori.

According to Rawls, the conception of a Kantian self is not intended to describe a "real" person. Recall that the parties in the original position are representatives of persons. The aspects of the original position, including the Kantian self, “...are to represent the freedom and equality of moral persons as understood in [a wellordered] society." 17 Citizens will agree to this Kantian self, though they themselves may hold different ideas of a person, because "...they have...agreed that, for certain parts of their common life, considerations of justice are to have a special [i.e., privileged] place."1 8

It is important to note here that Rawls's theory of constructivism contains the idea that the "public" self and the "private" self are separate, and inhabit different realms with different characteristics:

[In contrast to the public conception of justice in a well-ordered society]...citizens in their personal affairs, or within the internal life of associations, may regard their ends and aspirations differently. They may have attachments and loves that they believe they would not, or could not, stand apart from; and they might regard it as unthinkable for them to view themselves without certain religious and philosophical convictions and commitments. But none of this need affect the

17"Kantian Constructivism," p. 520.

18"Kantian Constructivism," p. 539. 
conception of the person connected with

society's public conception of justice and its ideal of social cooperation. ${ }^{19}$

We can observe here the movement of Rawls's thinking towards a "political" conception of the person. The political self has no function other than the public one of constructivism. This public self will simply foster the values of social cooperation between persons. Because it inhabits the public realm which remains discrete from the private, it need not influence any individual's personal set of values or conception of the self. Rawls's claim that the public sphere will not unduly influence or determine the private will only hold, however, if these two are as separate as he understands them to be. I will examine this question further in chapter VI.

\section{KANTIAN CONSTRUCTIVISM AS A JUSTIFICATORY SCHEME}

With the establishment of a Kantian conception of the person, construction of the principles of justice as fairness can take place. The mechanisms and assumptions here are essentially the same as those in $T J .20$ Briefly, the (Kantian) persons in the original position, characterized as individual, rational choosers and with the limitations of a veil of ignorance, choose the two principles of justice. 21

19"Kantian Constructivism," p. 545.

${ }^{20}$ See chapter $1, \S 1$ of this paper.

${ }^{21}$ See chapter I, $\S 4$ of this paper. 
But why does Rawls go to the lengths that he does to clarify the Kantian concept of constructivism, if the procedure is so similar to the one found in TJ ? One of his objectives is to emphasize the neutrality of justice as fairness between private conceptions of the person and between their various ideas of the good. In a wellordered society, citizens will (hopefully) agree upon an objective set of principles of right. Rawls is careful to insist that he does not mean objective in any ultimate, universal sense: "Objectivity is [only] to be understood by reference to a suitably constructed social point of view, an example of which is the framework provided by the procedure of the original position."22

Part of this "social point of view" is the Kantian self. In constructivism, establishing this conception of the person
...may enable us to crystallize our otherwise amorphous notion of the person and to identify with sufficient sharpness the appropriate characterization of free and equal moral personality. ${ }^{23}$

Once again, Rawls claims that he is not attempting to discover what a person really is, or should be. The Kantian self represents an endeavor to utilize what Rawls believes are certain minimum characteristics of the self, namely the capacity for free and equal moral personality, in the construction of the principles of justice in a pluralist society. Rawls hopes that this conception will actually
22"Kantian Constructivism," p. 570.
23“Kantian Constructivism," p. 572. 
help foster social and communal values. This will be done by using the institutions of justice determined by Kantian constructivism to mediate between the various private conceptions of a self that will exist in a democratic society.

As I noted above, "Kantian Constructivism" contains the elements of Rawls's move towards a more political conception of justice as fairness. The Kantian self is to be used in a process of construction to justify principles of justice for a liberal society. This self is derived from elements found in our culture, and represents these elements in the justificatory process. However, this self is only germane to the public sphere. Individuals acting privately are thus enabled to hold different and even conflicting conceptions of the self. This move is made explicit in the next article that 1 will discuss, "Justice as Fairness: Political not Metaphysical."24

\section{JUSTICE AS FAIRNESS: POLITICAL NOT METAPHYSICAL}

Briefly [says Rawls], the idea [of "Justice as Fairness: Political not Metaphysical"] is that in a constitutional democracy the public conception of justice should be, so far as possible, independent of controversial philosophical and religious doctrines. Thus, to formulate such a conception, we apply the

24"Justice as Fairness: Political not Metaphysical," Philosophy and Public Affairs 14 (1985): p. 223-51, hereafter referred to as "Political not Metaphysical." 
principle of toleration to philosophy itself:

the public conception of justice is to be political, not metaphysical...25 I do this because it may seem that [justice as fairness] depends on philosophical claims I should like to avoid, for example, claims to universal truth, or claims about the essential nature and identity of persons. 26

One of the ways in which justice as fairness can be seen as a political conception is to distinguish political morality from private morality: "While a political conception of justice is, of course, a moral conception, it is a moral conception worked out for a specific kind of subject, namely, for political, social, and economic institutions." 27 Rawls stipulates that this political sense of morality is "...not intended as the application of a general [private] moral conception to the basic structure of society...."28 For Rawls, this is unfeasible because: "...as a practical political matter no general moral conception can provide a publicly recognized basis for a conception of justice in a modern democratic state."29

If we cannot use a particular private moral conception as a basis for the establishment of principles of justice, we must establish a general political morality:

25 "Political not Metaphysical," p. 223.

26"Political not Metaphysical," p. 223.

27"Political not Metaphysical," p. 224.

28"Political not Metaphysical," p. 225.

29 "Political not Metaphysical," p. 225. 
One task of political philosophy in a democratic society is to...examine whether some underlying basis of agreement can be uncovered and a mutually acceptable way of resolving [political controversy] publicly established...30

We look, then, to our public political culture itself, including its main institutions and the historical traditions of their interpretation, as the shared fund of implicitly recognized basic ideas and principles. The hope is that these ideas and principles can be formulated clearly enough to be combined into a conception of political justice congenial to our most firmly held convictions. ${ }^{31}$

This conception of a shared political morality indicates two problems for Rawls's conception of justice that would be political, not metaphysical. First, he must find the areas of common ground that are available in "...the public political culture of a constitutional regime...." 32 If he succeeds in finding this zone of commonality, he must then show that it does not rest upon controversial metaphysical claims. Otherwise, justice as fairness cannot legitimately be called a political conception in the sense that Rawls wishes.

30"Political not Metaphysical," p. 225.

31 "Political not Metaphysical," p. 228.

32"Political not Metaphysical," p. 229. 


\section{THE COMMON IDEA OF A SELF IN A POLITICAL CONCEPTION}

Rawls is very clear about where he thinks the common ground of a political conception may be found:

...the overarching fundamental intuitive idea [of a political conception of justice], within which other basic ideas are systematically connected, is that of a society as a fair system of cooperation between free and equal persons. ${ }^{33}$

Several elements appear to be present in this formulation, namely "a fair system of cooperation," and "free and equal persons." Rawls claims that the first element (the systemic) is prior to and determinate of the second element (the personal): "Justice as fairness starts from the idea that society is to be conceived as a fair system of cooperation and so it adopts a conception of the person to go with this idea." 34

But this is a strange assertion. Why would we want to characterize a system as "fair," without having a prior conception of the characteristics of the objects that are to be treated fairly? Imagine a predator tracking, killing, and eating its prey in the "system" of nature. It is inappropriate to describe this system as either fair or unfair unless we establish a normative relationship between these two actors (predator and prey). If we judge them to be equal, we may evaluate the fairness of the system. But we cannot

33"Political not Metaphysical," p. 231.

34"Political not Metaphysical," p. 232-233. 
make such an evaluation without first making this normative judgment. If the question of normative equality between the two is not established, the system is neither fair nor unfair-it just "is."

Analogously, understanding a social system as fair or unfair presumes a judgment about the nature of persons. It is our considered view that the Third Reich was an unfair system, since it did not treat those whom we believe to be equal, for instance Jews and Gentiles, in a manner that corresponds to our normative conviction. Notice that someone who holds an opposing attitude, perhaps a Nazi official, would not see the Third Reich as unfair. And someone who held no attitude about persons at all, say a Martian, would have no basis on which to judge a system's fairness.

Thus, the conception of persons as free and equal moral selves is prior to the idea of a fair society. We cannot start with the latter, and work towards the former, as it seems Rawls wants to do:

Since we start within the tradition of democratic thought, we also think of citizens as free and equal persons.... ${ }^{35}$

Now the conception of persons as having the two moral powers, and therefore as free and equal, is also a basic intuitive idea assumed to be implicit in the public culture of a democratic society. ${ }^{36}$

It is understandable why Rawls does not wish to claim that a particular conception of the person underlies this political

35“Political not Metaphysical," p. 233.

36"Political not Metaphysical," p. 234. 
conception. Remember that he wishes to allow the widest possible range of private conceptions of the self. Thus, justice as fairness is based upon the weakest possible conclusions. A comprehensive ideal of the self might be seen as too strong a conception to allow neutrality. Just as Rawls does not want to base his theory on a comprehensive moral doctrine, he also does not want to found it upon a fully developed idea of the self.

For the moment, let us grant Rawls's contention that his political conception of the person is implicit in our democratic culture. How can he defeat charges that this political idea of the self is actually a comprehensive moral conception?

...[P]ersons can accept this [political]
conception of themselves as citizens and use
it when discussing question of political
justice without being committed in other
parts of their life to comprehensive moral
ideals often associated with liberalism, for
example, the ideals of autonomy and indi-
viduality. The absence of commitment to
these ideals, and indeed to any particular
comprehensive ideal, is essential to
liberalism as a political doctrine. ${ }^{37}$

Thus, Rawls asserts that justice as fairness can avoid the problems associated with those liberalisms, such as utilitarianism and perfectionism, that he believes are 'comprehensive moral doctrines:'

[A private moral doctrine], when pursued as a comprehensive ideal, is incompatible with other conceptions of the good, with forms of personal, moral, and religious life consistent

37"Political not Metaphysical," p. 245. 
with justice and which, therefore, have a

proper place in a democratic society...So

understood, liberalism becomes but another

sectarian doctrine. 38

Here, Rawls takes an initial step toward an idea that he will develop in a later article:
...justice as fairness seeks to identify the kernel of an overlapping consensus, that is, the shared intuitive ideas which when worked up into a political conception of justice turn out to be sufficient to underwrite a just constitutional regime. 39

By identifying this consensus, Rawls hopes that socio-political cooperation can be achieved without the problems associated with teleological theories. Rawls rejects, on moral and pragmatic grounds, attempts by the state to enforce conformity to a single private moral conception. But if an overlapping consensus is realized, Rawls believes that society can establish just institutions without compromising the values of individuals.

\section{THE IDEA OF AN OVERLAPPING CONSENSUS}

Though Rawls hopes to establish just institutions without violating the sanctity of individuals, he wishes to distance himself from the hyper-individual minimal state of thinkers such as Robert

38"Political not Metaphysical," p. 245-246.

39"Political not Metaphysical," p. 246-247. 
Nozick. 40 Recall that Rawls conceives of justice as fairness as a "...social union of social unions." 41 This is an important idea, since Rawls holds the Humboldtian view "...that it is through social union founded upon the needs and potentialities of its members that each person can participate in the total sum of the realized natural assets of the others." 42 As I noted in chapter I, $\$ 6$ above, Rawls believes that justice as fairness can provide for important communal values if we understand it as a social union of social unions.

This emphasis on community as fulfilling human potential has been modified somewhat by Rawls's more recent formulation of his political conception of justice as fairness, which is the overlapping consensus. Now he expresses a concern for the pragmatic political "realities" of a pluralist society. This can be seen in Rawls's article "The Idea of an Overlapping Consensus." In this article Rawls expands upon the concept of a shared political conception that does not significantly interfere with whatever private conceptions individuals in democratic states may hold.

In "Overlapping Consensus," Rawls claims that one of the most important aims of political philosophy is

${ }^{40}$ See Nozick's Anarchy, State and Utopia. New York: Basic Books, 1974.

$$
41 \text { TJ, p. } 527 .
$$

$42 T J$, p. 523. See footnote $4, \S 79$, p. 523 of $T J$ for Rawls's acknowledgement of his debt to Humboldt. 
...presenting a political conception of justice that can not only provide a shared public basis for the justification of political and social institutions but also helps ensure stability from one generation to the next. Now a basis of justification that rests on self- or group-interests alone cannot be stable; such a basis must be, I think, even when moderated by skilful constitutional design, a mere modus vivendi, dependent on a fortuitous conjunction of contingencies. ${ }^{43}$

To illustrate the concept of a modus vivendi, Rawls uses the example of a treaty between two states whose interests are opposed. It is rational and prudent for each to negotiate this treaty so that it represents a type of equilibrium point: “...that is, that the terms and conditions of the treaty are drawn up in such a way that it is public knowledge that it is not advantageous for either state to violate it." 44 Thus, each state will adhere to the terms of the treaty solely because it is perceived to be in its own best interest. Neither state is motivated by any feeling of common purpose shared with the other state, and each state will violate the pact if the circumstances change and they regard it as a rational choice to do so. 45

Rawls believes that the idea of a modus vivendi is too individualistic for his conception of justice. Remember that he has claimed that justice as fairness should not be seen as merely a

43"Overlapping Consensus," p. 1.

44"Overlapping Consensus," p. 10.

45"Overlapping Consensus," p. 10-11. 
"private society," in which completely self-motivated individuals establish and use the institutions of society solely as instrumental means to their private ends. ${ }^{46}$ Rather, the Kantian conception of persons means that they are acting as autonomous moral beings when they choose institutions convergent with communal or shared ends. Additionally, a modus vivendi does not ensure the requisite stability of a just society. In a modus vivendi persons contract only because contingent circumstances cause them to believe that it is in their own personal interest to do so. When these circumstances change, as Rawls feels is inevitable, any communal bonds formed will disintegrate.

Rawls gives two primary ways in which the conception of a modus vivendi differs from an overlapping consensus. First, where the modus vivendi is not a moral conception, the overlapping consensus is. I have noted the specific aspects of Rawls's idea of a political idea of morality above. 47

Next, the overlapping consensus

...is affirmed on moral grounds, that is, it includes conceptions of society and of citizens as persons, as well as principles of justice, and an account of the cooperative virtues through which those principles are embodied in human character and expressed in human life. 48

${ }^{46}$ See chapter $1, \S 6$ above.

${ }^{47}$ See this chapter, $\S 4$ above.

48"Overlapping Consensus," p. 11. 
A modus vivendi needs no such moral affirmation, since persons agree to it only because they perceive it as rational to do so.

\section{ASPECTS OF THE OVERLAPPING CONSENSUS}

Why does Rawls claim that this political conception of the structure of justice as fairness is necessary? Rawls thinks that

...as a practical political matter, no general and comprehensive view can provide a publicly acceptable basis for a political conception of justice...[A] diversity of doctrines-the fact of pluralism-is not a mere historical condition that will soon pass away; it is, I believe, a permanent feature of the public culture of modern democracies. ${ }^{49}$

Unless we resort to an "...oppressive use of state power," 50 which Rawls is opposed to, we cannot establish allegiance to a single comprehensive morality.

Of course, the overlapping consensus must be based upon some idea. For Rawls, it has its foundations in "...certain fundamental intuitive ideas viewed as latent in the public political culture of a democratic society." ${ }^{1}$ Rawls sees these ideas as arising out of the tradition of political discourse, in a dialectical fashion: “...these

49"Overlapping Consensus," p. 4.

50"Overlapping Consensus," p. 4.

51"Overlapping Consensus," p. 6. 
rival conceptions will then compete for citizens' allegiance and be gradually modified and deepened by the contest between them." 52

But Rawls is careful to insist that he is not referring to a consensus on comprehensive moral, religious or philosophical issues:

What is important is that, so far as possible, these fundamental intuitive ideas are not taken for religious, philosophical or metaphysical ideas. For example, when it is said that citizens are regarded as free and equal persons, their freedom and equality are to be understood in ways congenial to the public political culture and explicable in terms of the design and requirements of its basic institutions. 53

The overlapping consensus deals only with the issues of public morality, as discussed in this chapter, $\S 4$ above.

Rawls concedes that there may be instances where

...we may eventually have to assert at least certain aspects of our own comprehensive...religious or philosophical doctrine. This happens whenever someone insists, for example, that certain questions are so fundamental that to ensure their being rightly settled justifies civil strife. 54

In these cases, we must only assert the smallest part of our private moral view necessary for the establishment of a political consensus.

52“Overlapping Consensus," p. 6.

53"Overlapping Consensus," p. 7.

54"Overlapping Consensus," p. 14. 
Rawls notes that we do this "...to respect, as best we can, the limits of free public reason." 55

\section{OBJECTIONS TO THE OVERLAPPING CONSENSUS}

Rawls fields in advance four possible objections to the idea of an overlapping consensus. The first is that an overlapping consensus is merely a modus vivendi, with the latter's attendant problems. I have discussed this objection in $\S 7$, above.

Next, Rawls discusses the objection that "...the avoidance of general and comprehensive doctrines implies indifference or skepticism as to whether a political conception of justice is true." 56 But Rawls is really only concerned with truth in the political sense mentioned above. ${ }^{57} \mathrm{He}$ is not trying to establish transcendent reality, but merely to justify a system that he hopes will prove reasonable to persons with various conceptions of the self and of their own good.

Rather than an indifference to truth, the overlapping consensus incorporates the standard liberal value of tolerance: "[w]e simply apply the principle of toleration to philosophy itself." 58 As far as it can, a just society will tolerate all viewpoints. Obviously, some

55“Overlapping Consensus," p. 14.

56“Overlapping Consensus," p. 12.

57 See this chapter, $\S 1$ above.

58“Overlapping Consensus," p. 13. 
views will be controversial, but then we may "...appeal to a political conception of justice to distinguish between those questions that can reasonably be removed from the political agenda and those that cannot, all the while aiming for an overlapping consensus."59

The third objection that Rawls mentions is:

...even if we grant that an overlapping consensus is not a modus vivendi, it may be said that a workable political conception must be general and comprehensive...[otherwise], there is no way to order the many conflicts of justice that arise in public life. 60

In response to this objection, Rawls notes that the overlapping consensus is a partially comprehensive view, only "...sufficient to express values that normally outweigh whatever other values oppose them, at least under the reasonably favorable conditions that make a constitutional democracy possible."61 Citizens in a well-ordered society believe that, "...within the scope allowed by the basic liberties and the other provisions of a just constitution, all citizens can pursue their way of life on fair terms and properly respect [their private moral] values." 62

59“Overlapping Consensus," p. 13.

60"Overlapping Consensus," p. 15.

61"Overlapping Consensus," p. 16.

62“Overlapping Consensus," p. 16. 
It is clear, then, that these political values must not be held simply because of an individual's personal calculation of her interest, as in a modus vivendi. The political virtues

...of political cooperation that make a
constitutional regime possible are, then, very
great virtues. I mean, for example, the
virtues of tolerance and being ready to meet
others halfway, and the virtue of
reasonableness and the sense of fair-
ness... [these virtues] constitute a very great
public good... [italics in original]. ${ }^{3}$

In some sense, then, Rawls maintains that persons in a constitutional democracy hold these values of political cooperation in common, as a part of the political morality which is the basis for the overlapping consensus. They are a public (i.e., political) good.

The last objection that Rawls considers is that the overlapping consensus is utopian: "that is, there are not sufficient political, social, or psychological forces either to bring about an overlapping consensus (when one does not exist), or to render one stable (should one exist)."64 Rawls outlines a possible scenario in which this consensus might come about. Assume that a group of persons have accepted a generally liberal set of principles as a modus vivendi. Rawls notes that with many people, their

...religious, philosophical and moral doctrines are not seen by them as fully general and comprehensive, and these aspects admit of

63"Overlapping Consensus," p. 17. 64“Overlapping Consensus," p. 18. 
variations of degree. There is lots of

slippage, so to speak, many ways for the

political conception to cohere loosely with

those (partially) comprehensive views, and

many ways within the limits of a political

conception of justice to allow for the pursuit

of different (partially) comprehensive

doctrines... Hence it is possible for them first

to affirm the political conception and to

appreciate the public good it accomplishes in

a democratic society. Should an

incompatibility later be recognized between

the political conception and their wider

doctrines, then they might very well adjust

or revise these doctrines rather than reject

the political conception. 65

Thus, the parties to the modus vivendi may come to believe in the shared concepts and values of political cooperation that Rawls sees as the basis for an overlapping consensus.

\section{ON THE IDEA OF FREE PUBLIC REASON}

In his unpublished paper, "On the Idea of Free Public Reason," Rawls extends one of the concepts of a political conception of morality that he introduced in "The Idea of an Overlapping Consensus." 66 The basic idea of the paper is as follows:

65“Overlapping Consensus," p. 19.

66This paper was delivered on March 28, 1988. Rawls's handwritten note at the top of the manuscript is as follows: "This is at best work in progress, if not in retrogression. For Conference use only, I hope. JR" Though I see the work as a logical extension of the line of thought that I have been exploring in this chapter, Rawls himself may see otherwise. For this reason, and because Rawls has 
...while political power is always, of course, coercive--backed by the government's monopoly of legal force--in a democratic regime it is also the power of the public: that is of free and equal citizens as a corporate body. Therefore, political power must be exercised in ways that all citizens can publicly endorse before one another in the light of their own reason. Only in this way can the political conception of justice provide a public basis of justification...67

But given the fact of pluralism, and given the aim of seeking an overlapping consensus, how are these guidelines for public inquiry best specified for questions concerning constitutional essentials? Here there seems to be no reasonable alternative to adopting the criteria and procedures of common sense knowledge that all of us recognize and use, and the methods and conclusions of science when these are not controversial. 68

This appears to be an expansion of the idea of the overlapping consensus discussed above. Rawls apparently feels we can find a shared basis of public reason, and that this can provide the procedure for establishing a shared political consensus on principles of justice.

indicated that it is an uncompleted work, I will limit my discussion to a mention of the basic ideas of the paper only.

67"On the Idea of Free Public Reason," p. 1.

68"On the Idea of Free Public Reason," p. 2. 


\section{CONCLUSION: FROM METAPHYSICAL TO POLITICAL}

We can trace the development of Rawls's political conception of justice through his work in the decade of the 1980's. Rawls is a (self-professed) liberal, and liberals traditionally value tolerance. The original theory of justice in $T J$ is an attempt to build a political edifice that could tolerate the widest possible variety of human conceptions of the good, while still retaining the advantages of social union. This would enable Rawls to construct a theory that respected the differences between persons, unlike his perception of the dominant utilitarian tradition.

As I discussed in chapter III and IV, many felt that Rawls's attempt to construct a political theory that encouraged communal values from an individualist standpoint had failed. Rawls's conception of the self was either incomplete for his stated purposes, or was not as neutral as he had insisted.

Rawls's response to these communitarian critics has been to move his theory further away from attempts to find universal or metaphysical principles. He now insists that justice as fairness need not presume any controversial ideas about what the self is or what is true. Justice as fairness is political, not metaphysical. The grounds for the political idea of morality that he postulates are to be found in the intuitive ideas of the persons that he thinks exist in our democratic culture. We may thus establish an overlapping consensus, which will preserve communal values but which will allow persons to retain their own private moral conceptions. 
96

In the final chapter of this paper, I will consider the question of whether Rawls has succeeded in his response to the communitarian critique of the self. 


\section{CHAPTER VI}

\section{FROM METAPHYSICAL TO POLITICAL_AND BACK}

In this final chapter, I will evaluate Rawls's changing conception of the person, and the place of this amended idea of a self in justice as fairness. Rawls has shifted the emphasis of his conception of the self from metaphysical to political, in order to refute the communitarian criticisms of an unsituated self. But he has also retained certain aspects of the metaphysical self, without which his theory would flounder. I will argue that for justice as fairness to be viable, it must presume a public idea of the self that is neutral between private conceptions. And if Rawls is to successfully rebut the communitarian critique, this idea must itself be coherent.

\section{THE SHIFT FROM METAPHYSICAL TO POLITICAL}

It is apparent that Rawls did not set out primarily to develop a metaphysical ideal of the ultimate self in $A$ Theory of Justice. Rather, $T J$ is an attempt to examine the relationship of Rawls's perception of the dominant political tradition, utilitarianism, with certain aspects of persons that he believes are inherent in our 
culture. The latter refers to the idea of people as being, at least, free and equal moral individuals.

Rawls sees these characteristics as incompatible with utilitarian assumptions. Since individuals have (at least the potential for) moral personality, we must not sacrifice even one of them for a greater "good." In $T J$, then, Rawls has attempted two things. First, he develops an idea of the self based upon its moral aspects of freedom and equality. Using the process of reflective equilibrium, in which certain intuitive ideas are subjected to consideration and development, Rawls expands the notion of what it means to be a free and equal person.

Next, he uses this expanded vision of a self in his version of the social contract doctrine-the original position. Rawls claims that free and equal persons, with the characteristics that he develops using reflective equilibrium, will choose the two principles of justice that comprise justice as fairness.

However, the idea of the self (and his development of it) that Rawls presumed was inherent in our political culture was not as uncontroversial as he originally believed. In chapters III and IV of this paper I discussed criticisms raised against the Rawlsian self by communitarian critics. This line of criticism, and Rawls's continuing consideration of his theory led to a shift in emphasis. This is the movement from a metaphysical to a political conception of the idea of a self that I described in chapter $V$ above.

Much of the communitarian critique of Rawls's idea of the self is aimed at its perceived abstracted quality. Since politics involves 
the mediation between persons with different interests, how can we determine principles of justice from an idea of a self that is unaware of its particular interests? Rawls's deontological self has "...rights secured by justice [which] are not subject to the calculus of social interests." 1 But according to the communitarians, this implies a type of transcendent, metaphysical self, which is prior to any social or physical contingencies. By assuming a self that is not situated in any particular culture, Rawls has robbed it of precisely the things that constitute the quality of being human. This is, of course, a similar critique to that put to the Kantian noumenal self by Hegel.2

Rawls's response to these charges has been to situate his theory in an actual political culture-specifically, in the western democratic tradition: "...justice as fairness is intended as a political conception of justice...framed to apply to what I have called the basic structure' of a modern constitutional democracy." 3 In chapter $V, I$ traced the development of a political, not metaphysical conception of the self presumed by justice as fairness.

\section{THE "KANTIAN SHELL" AS A FOUNDATION OF JUSTICE AS FAIRNESS}

This political conception requires some philosophical maneuvering to realize, however. While Rawls needs to situate his theory in a political culture to avoid the charges associated with a

$1 T J$, p. 4.

2This observation is from Dr. Craig Carr.

3"Political, not Metaphysical," p. 224. 
metaphysical conception, it is still necessary that the Rawlsian self retain some distance from the culture as well. In order for justice to be fair on Rawls's understanding of the term, persons must be represented as equal moral beings. Since persons' moral equality is prior to and more important than their contingent attributes (because these are the results of the natural lottery and thus morally arbitrary), they must not be able to use knowledge of these attributes to determine a system of justice that advantages some, which would be unfair.

Also, a completely situated political conception would prima facie violate the liberal value of tolerance. By choosing a single comprehensive moral conception for society, even if it is held by a numerical majority, the right would no longer be prior to the good. Other conceptions of the good that are incommensurable with the official conception would be unwelcome. Given the fact of pluralism, it would be likely that oppressive state power would be necessary to enforce obedience to this good.

Rawls's solution for avoiding either an overly metaphysical conception or an overly situated one is to establish distance between the public and the private spheres. In the private sphere, any conception of the good is allowable, so long as its exercise does not violate principles of right. The public sphere is configured differently, however. It is based upon a limited conception of a person that I will call the "Kantian shell." 4 The Kantian shell is a

${ }^{4}$ This phrase, and the associated discussion, was suggested to me by Dr. Craig Carr. 
set of characteristics of persons that Rawls claims are deducible from our culture. These characteristics are the attributes discussed in "Kantian Constructivism," namely freedom, equality and moral personality. By positing a self that has these attributes, we may "construct" the principles of justice that will reflect these characteristics effectively.

Though this is a type of moral conception, it is limited to the political sphere. As Rawls notes, the only public moral "facts" are those derived from Kantian constructivism. ${ }^{5}$ But of course this Kantian self must be publicly and freely supported, even by nonKantians. This is accomplished through the idea of an overlapping consensus. In a society governed by an overlapping consensus, persons agree that regardless of whatever private moral conceptions they may have, they share a consensus on the aspects of the self that are represented by the Kantian shell. They do so not merely because it is in their immediate best interests to do so, but because despite their differences, they conceive of their selves as being encompassed by the Kantian shell.

In this way, Rawls attempts to establish a system of justice that is fair, according to a metaphysical conception, but situated, according to a political conception. In justice as fairness, we may hold whatever conception of ourselves we wish, so long as it fits within the Kantian shell. Since public and private are divided into fairly discrete spheres, our "true" self (as we understand it) need not be overly influenced by the public self. We still retain the 
option for communal values, but without the violation of the bounds of the self that utilitarianism presumes.

\section{A NEUTRAL CONCEPTION?}

If justice as fairness is to be fair in the way Rawls intends it to be, the public conception of the self that it is based upon must be substantively neutral between private conceptions of the good, and of the self. Rawls affirms this when he states:

The conception of the citizen as a free and equal person is not a moral ideal to govern all of life, but is rather an ideal belonging to a conception of political justice...to think otherwise would be incompatible with liberalism as a political doctrine... The absence of commitment to [comprehensive moral ideals], and indeed to any particular comprehensive ideal, is essential to liberalism as a political doctrine. The reason is that any such ideal, when pursued as a comprehensive ideal, is incompatible with other conceptions of the good....6

The idea of the self as free and equal is used to justify principles of the right, not the good. Otherwise, liberalism becomes "...but another sectarian doctrine."7

As I noted above, Rawls solution to the problem of neutrality is to propose the idea of a Kantian shell which represents certain aspects of the public self found in our culture, and which is supported by an overlapping consensus. But assuming a consensus 
could be "identified," who would determine what its specifics were? Setting a neutral rule is fine if we can find a truly neutral arbiter to apply and interpret it. It is likely, however, that no judge from within a given culture is truly neutral. As Rawls himself notes, in the original position an individual's particular knowledge of her talents and abilities and the characteristics of the society in which she will exercise them will render a process of this sort unfair. This is why Rawls insists upon a veil of ignorance in the original position.

No such veil is possible in a real political culture, however. Some person, or group, must identify the characteristics of persons that will serve for an overlapping consensus. And this conception must be universally acceptable to the citizens of this society, if neutrality is to obtain. If Rawls claims that we cannot come to a unanimous decision about anything (as he must, given his assertion of pluralism), he will run afoul of the same problems that are to be found with utilitarianism.

A neutral judge of the overlapping consensus from without the culture is equally untenable. Initially, it would be difficult to find a judge who had absolutely no vested interest in the culture that she would examine. And who would determine whether she did or did not? Beyond this, however, it is essential that a judge evaluate a culture on its own terms. For example, the words "freedom" and "law" have different meaning in, say, an Islamic culture than they do in ours. It would do no good to appraise an overlapping consensus within a culture using words and concepts from without. 
Let us assume, however, that the question of determining a neutral conception has somehow been solved. Is it likely that Rawls's political, not metaphysical conception would be seen as neutral, even within our own culture?

Since the Kantian shell determines the principles of the right, which are prior to all particular conceptions of the good, individuals under justice as fairness must hold the Kantian shell as a part of their conception of the person. Rawls claims otherwise; since the Kantian shell is only a public conception, individuals may hold other, potentially incompatible, ideals. But how could this be so?

Assume that I hold a view of persons that scales moral worth (in a positive direction) according to scores on a test of intelligence. Additionally, my code requires that I treat those with higher moral value better than those with a lower value, and that those who fall below a certain standard must be killed because of their moral inferiority. Clearly, this is incompatible with justice as fairness. But if 1 am to live in this society, 8 I must hold the Kantian shell as part of my conception of persons. If I do not, the state will undoubtedly use its monopoly of force to prevent me from acting upon my beliefs. It will not do to claim that the state is still neutral in allowing citizens to hold views incompatible with justice as fairness, as long as they do not act on the parts that are in violation of the principle of right. To hold a conception of the good is to want to live according to that conception. Insofar as the state

$8 \mid$ will presume for the sake of argument that emigration is not a viable option. 
does not allow me to act on my beliefs, it prevents me from having conceptions of the good that are incommensurable with the public conceptions of the right. In the place of my personal conceptions of the good are substituted public principles. If we all act according to the principles of the good that we hold, then the public principles of right which are substituted for our unacceptable private goods actually function as private goods, whether we want them or not.

If we could determine a conception of the self that was incontestable by "rational" persons, we could claim that this idea was truly neutral. In deconstructionist terms, it would be an empty vessel into which anything could be poured. But Rawls has attempted to fend off communitarian critics by deriving the Kantian shell from ideas that he understands as inherent in our political culture. These are the substantive facts of "moral anthropology" that Rawls is attempting to shield the parties in the original position from by use of the veil of ignorance.

Rawls is thus caught on the horns of a dilemma. If his idea of the self is metaphysical, it may be fair and neutral. But, this metaphysical self is also too abstracted from the things that make it "real," such as experience, self-knowledge, and cultural values. If the Rawlsian self is derived from substantive aspects of a particular social tradition, however, it cannot claim to be neutral. Someone will be benefited from this choice, while some will suffer a loss as their preferred ideas of the self are relegated to the limited private sphere. Rawls cannot have a coherent idea of the person that has the metaphysical advantages of fairness and 
neutrality, and the situated advantages of a political conception. His attempt to separate the public and the private spheres is untenable, since the public must intrude on the private exactly in the degree that the latter is incompatible with the former.

\section{THE INCOMPLETE INDIVIDUAL}

Individualism has a strong hold upon the citizens of the western political tradition. The United States has a long tradition of "rugged individualists," who left their comfortable society in search of wealth or freedom, that dates to its earliest settlers. More Americans are probably familiar with the Declaration of Independence, a separating document, than with the Constitution, a coalescing one.

But the notion of individualism is more complex than it may appear. As Taylor observes in "Atomism," individualism is itself a situated concept. 9 Aside from the question of whether we could physically survive completely separate from a culture, Taylor makes a forceful case that we would not be truly human. We learn our interpretation of the world from cultural sources, and in this way, "pass on" the traits of humanity. The creature with human genes that could somehow survive independently of a culture would likely not bear any recognizably human characteristics, other than a human visage. 
The idea of an individual is thus inextricably linked with an associated culture. For example, it is possible to separate cardiac cells from the host organism, and to keep these "alive" by artificial means. This might occur in an organ transplant operation. Separate from a man or woman, though, a heart is just tissue. It has an historical relationship with its original owner, and a potential relationship with its recipient. And in other frames of reference, it could be seen in many other ways. But we cannot evaluate it without some idea of what it is related to. Its identity is situationally relative. We can only assess the propriety of any given description by knowing the ground-rules ahead of time. To call something a heart without having a concept of the kind of organism that might have one would be incoherent.

Rawls has posited an antecedently individuated self that will be used for the purposes of establishing a system of justice. Now of course Rawls is not claiming that we are starting society anew, building up ideas from nothing. According to him, the individual liberal self is distilled from concepts present in a long historical tradition, dating at least back to the Enlightenment. But while it can be argued that individualism is an aspect of our idea of the self, we cannot separate the idea of an individual from the cultural context in which it is situated. If we do, the result is not philosophically viable. We may examine the parts of the self that are individualistic, just as we may observe parts of the human body in isolation. But these parts will remain incomplete, at least in the particular human frame of reference that we are interested in. 
Now Rawls appears to believe that communal values are part of the essential good for all human beings. Recall his insistence that

[i]t is a feature of human sociability that we are by ourselves but parts of what we might be. We must look to others to attain the excellences that we must leave aside, or lack altogether. 10

But, to misstate an old saying, Rawls is trying to get communal blood out of individualistic turnips. In the quotation above, it appears that we join together essentially so that we may promote our own advantage. This is similar to the idea of a person as a collection of cells that have joined together to remain alive.

Rawls's attempt to claim that individuals are acting according to their Kantian autonomy when they establish a just culture seems dubious. How may they possess this autonomy outside of a culture in the first place?

Rawls states his belief early on in $T J$ that "[e]ach person possesses an inviolability founded on justice that even the welfare of society as a whole cannot override."11 But this inviolate individual self is but a part of a larger idea of a person that is embedded in a culture. Rawls introduces this incomplete self into the original position, where it chooses principles appropriate to its incomplete understanding of the world. It has no motivations but the advancement of its own interests, and so it will naturally opt for institutions and ideas that are self-serving, in the truest sense.

10 TJ, p. 529.

$11 T J$, p. 3. 


\section{CONCLUSION}

The Rawlsian idea of the self thus fails on at least two counts. Though it must be neutral in order to remain tolerant of various conceptions of the good, it cannot achieve neutrality. A metaphysical idea of the self is too abstract to serve Rawls's purposes. But in his move to situate it in a political tradition, Rawls necessarily sacrifices neutrality. Rawls's liberal value of tolerance of competing conceptions of the good cannot be maintained.

Second, the individual Rawlsian self is incoherent and incomplete. Individualism is certainly an important aspect of being a person. But Rawls has unsuccessfully tried to distill this characteristic from the larger social environment. The incomplete individual selves in the original position thus make choices that are incompatible with the communal values that are an important part of our existence.

In justice as fairness, Rawls has reconsidered the balance between individual concerns and community values in a new way. As a bearer of the liberal standard, he has attempted to posit a self that is an individual, equal, moral being. Sensitive to societal considerations, Rawls has attempted to derive shared and communal values from these individualist premises. But though this proposed balance between the individual and society is a laudable aim, Rawls's proposal as it currently stands must ultimately fall short. Incomplete or poorly constructed parts must not serve as the basis 
for an edifice of the size and importance necessary for a conception of society. Ersatz liberal neutrality cannot unify a pluralistic culture. 


\section{REFERENCES}

Altman, Andrew. Critical Legal Studies: A Liberal Critique.

Princeton NJ: Princeton University Press, 1990.

Arneson, Richard. "Introduction." Ethics, v. 99 \#4 (July 1989): p.

695-710.

Baier, Kurt. "Justice and the Aims of Political Philosophy." Ethics v. 99 \#4 (July 1989): p. 771-790.

Barber, Benjamin. The Conquest of Politics: Liberal Philosophy in Democratic Times. Princeton NJ: Princeton University Press, 1988.

Baumgold, Deborah. "Liberal Individualism Reconsidered." Libera/s on Liberalism. Ed. Alphonso J. Damico. Totowa NJ: Rowman and Littlefield, 1986. P. 151-156.

Berger, Peter. "On the Obsolescence of the Concept of Honour." Liberalism and its Critics. New York: New York University Press, 1984. P. 149-158.

Berlin, Isaiah. "Two Concepts of Liberty." Four Essays on Liberty.

London: Oxford University Press, 1969. P. 118-172.

Buchanan, Allen E. "Assessing the Communitarian Critique of Liberalism." Ethics, v. 99 \#4 (July 1989): p. 852-882.

Damico, Alfonso J. Introduction. Liberals on Liberalism . Ed.

Alphonso J. Damico. Totowa NJ: Rowman and Littlefield, 1986.

P. 1-12.

Damico, Alphonso J. "The Democratic Consequences of Liberalism." Liberals on Liberalism. Ed. Alphonso J. Damico. Totowa NJ: Rowman and Littlefield, 1986. P. 167-184. 
Daniels, Norman. "Introduction." Reading Rawls . New York: Basic Books, 1973. P. xi-xxxiv.

Dawkins, Richard.The Selfish Gene. New York: Oxford University Press, 1976.

Doppelt, Gerald. "Is Rawls's Kantian Liberalism Coherent and Defensible?" Ethics, v. 99 \#4 (July 1989): p. 815-851.

Fishkin, James S. "Liberal Theory: Strategies of Reconstruction." Liberals on Liberalism. Ed. Alphonso J. Damico. Totowa NJ: Rowman and Littlefield, 1986. P. 54-66.

Flathman, Richard. Toward a Liberalism. Ithaca NY: Cornell University Press, 1989.

Gill, Emily R. "Goods, Virtues, and the Constitution of the Self" Liberals on Liberalism. Ed. Alphonso J. Damico. Totowa NJ: Rowman and Littlefield, 1986. P. 111-128.

Hampton, Jean. "Should Political Philosophy Be Done Without Metaphysics?" Ethics v. 99 \#4 (July 1989): p. 701-814.

Hart, H. L. A. The Concept of Law . Oxford: Clarendon Press, 1961.

---. "Rawls on Liberty and its Priority." Reading Rawls. New York: Basic Books, 1973. P. 230-252.

Höffe, Otfried. "Is Rawls' Theory of Justice really Kantian?" Ratio XXVI \#2 (1984): p. 103-124.

Hume, David. A Treatise of Human Nature. Ed. L.A. Selby-Bigge. Oxford: Clarendon Press, 1888.

Kant, Immanuel. Groundwork of the Metaphysic of Morals . Trans. H. J. Paton. New York: Harper and Row, 1948.

Kymlicka, Will. "Rawls on Teleology and Deontology." Journal of Philosophy and Public Affairs \#17 (1988), p. 173-190.

-.-. "Liberal Individualism and Liberal Neutrality." Ethics v. 99 \#4 (July 1989): p. 883-905. 
Macintyre, Alasdair. After Virtue. 2nd. ed. South Bend IN:

University of Notre Dame Press, 1984.

Nagel, Thomas. "Rawls on Justice." Reading Raw/s. New York: Basic Books, 1973. P. 1-15.

Rawls, John. A Theory of Justice . Cambridge, MA, The Belknap Press of Harvard University Press, 1971.

---. "Kantian Constructivism in Moral Theory: The Dewey Lectures 1980." Journal of Philosophy 77 (1980): p. 515-572.

--. "Justice as Fairness: Political not Metaphysical." Philosophy and Public Affairs 14 (1985): p. 223-251.

-.-. "The Idea of an Overlapping. Consensus." Oxford Journal of Legal Studies 7 (1987): p.1-25

---. "The Priority of Right and Ideas of the Good." Philosophy and Public Affairs \#17 (1988).

-.. "On the Idea of Free Public Reason." Unpublished paper (1988).

Sandel, Michael. Liberalism and the Limits of Justice. Cambridge: Cambridge University Press, 1982.

---. "Introduction." Liberalism and its Critics. New York: New York University Press, 1984.

Spragens, Thomas A. "Reconstructing Liberal Theory: Reason and Liberal Culture." Liberals on Liberalism. Ed. Alphonso J. Damico. Totowa NJ: Rowman and Littlefield, $1986 . \quad$ P. 34-53.

Taylor, Charles. Hegel . Cambridge: Cambridge University Press, 1975.

--. "Rationality." Rationality and Relativism. Ed. Martin Hollis and Steven Lukes. Cambridge, MA: MIT Press, 1982. P. 87-105. 
--.. "Atomism." Philosophy and the Human Sciences: Philosophical Papers II. Cambridge: Cambridge University Press, 1985. P. 187-210.

---. "Neutrality in Political Science." Philosophy and the Human Sciences: Philosophical Papers II. Cambridge: Cambridge University Press, 1985. P. 58-90.

---. "The Concept of a Person." Human Agency and Language:

Philosophical Papers I. Cambridge: Cambridge University Press, 1985. P. 97-114.

--. "What's wrong with negative liberty." Philosophy and the Human Sciences: Philosophical Papers II. Cambridge: Cambridge University Press, 1985. P. 211-229.

-.-. "The Nature and Scope of Distributive Justice." Justice and Equality, Here and Now. Ed. Frank S. Lucash. Ithaca NY: Cornell University Press, $1986 . \quad$ P. 34-67.

Unger, Roberto Mangabeira. Knowledge and Politics. New York: The Free Press, 1975.

-.-. The Critical Legal Studies Movement. Cambridge MA: Harvard University Press, 1983.

Winch, Peter. "Understanding a Primitive Society." American Philosophical Quarterly, 1 (1964): p. 307-324. 